\title{
Three-dimensional Magnetic Resonance Imaging of fossils across taxa
}

\author{
D. Mietchen ${ }^{1,2,3}$, M. Aberhan ${ }^{4}$, B. Manz ${ }^{1}$, O. Hampe ${ }^{4}$, B. Mohr ${ }^{4}$, C. Neumann ${ }^{4}$, and F. Volke ${ }^{1}$ \\ ${ }^{1}$ Fraunhofer Institute for Biomedical Engineering (IBMT), 66386 St. Ingbert, Germany \\ ${ }^{2}$ University of the Saarland, Faculty of Physics and Mechatronics, 66123 Saarbrücken, Germany \\ ${ }^{3}$ Friedrich Schiller University Jena, Department of Psychiatry, 07740 Jena, Germany \\ ${ }^{4}$ Humboldt-Universität zu Berlin, Museum für Naturkunde, 10099 Berlin, Germany
}

Received: 22 August 2007 - Published in Biogeosciences Discuss.: 27 August 2007

Revised: 30 October 2007 - Accepted: 14 December 2007 - Published: 23 January 2008

\begin{abstract}
The frequency of life forms in the fossil record is largely determined by the extent to which they were mineralised at the time of their death. In addition to mineral structures, many fossils nonetheless contain detectable amounts of residual water or organic molecules, the analysis of which has become an integral part of current palaeontological research. The methods available for this sort of investigations, though, typically require dissolution or ionisation of the fossil sample or parts thereof, which is an issue with rare taxa and outstanding materials like pathological or type specimens. In such cases, non-destructive techniques could provide a valuable methodological alternative. While Computed Tomography has long been used to study palaeontological specimens, a number of complementary approaches have recently gained ground. These include Magnetic Resonance Imaging (MRI) which had previously been employed to obtain three-dimensional images of pathological belemnites non-invasively on the basis of intrinsic contrast. The present study was undertaken to investigate whether ${ }^{1} \mathrm{H}$ MRI can likewise provide anatomical information about nonpathological belemnites and specimens of other fossil taxa. To this end, three-dimensional MR image series were acquired from intact non-pathological invertebrate, vertebrate and plant fossils. At routine voxel resolutions in the range of several dozens to some hundreds of micrometers, these images reveal a host of anatomical details and thus highlight the potential of MR techniques to effectively complement existing methodological approaches for palaeontological investigations in a wide range of taxa. As for the origin of the MR signal, relaxation and diffusion measurements as well as ${ }^{1} \mathrm{H}$ and ${ }^{13} \mathrm{C}$ MR spectra acquired from a belemnite suggest intracrystalline water or hydroxyl groups, rather than organic residues.
\end{abstract}

Correspondence to: D. Mietchen

(daniel.mietchen@uni-jena.de)

\section{Introduction}

When an organism dies, it is usually quickly decomposed but special conditions - namely the presence of biomineralised structures - sometimes allow for part of its morphological or biochemical characteristics to be preserved (for reviews, see Behrensmeyer et al., 2000; Briggs, 2003; Durand, 2003; Weiner and Dove, 2003; Middelburg and Meysman, 2007). Though these conditions only apply to a tiny minority of individual life forms at a given time, vast amounts of biogenic deposits have been accumulated over geological periods, most famously perhaps in the form of fossil fuels (e.g. Treibs, 1934; Brocks et al., 1999; Vandenbroucke, 2003) and sedimentary rock (Albrecht and Ourisson, 1971). Fossils, too, were increasingly often found to contain organic matter (Kidwell and Holland, 2002; Behrensmeyer et al., 2000; Briggs, 2003), be it in cephalopod shells (Abelson, 1954; Westbroek et al., 1979), belemnite rostra (Bandel and Spaeth, 1988; Florek et al., 2004), bones (Abelson, 1954; Schweitzer et al., 2005, 2007; Asara et al., 2007), or wood (Boyce et al., 2001; Siurek et al., 2004).

Such observations led to the suggestion that part of the organic material detected in fossils might actually represent the most stable portion of the molecules originally constituting the individual at the time of its death (e.g. Abelson, 1954; Florkin, 1965; Westbroek et al., 1979; Eglinton and Logan, 1991; Engel et al., 1994; Schweitzer et al., 2007), which opened the door for palaeobiochemical investigations (Blumer, 1965; Albrecht and Ourisson, 1971; Niklas and Gensel, 1976; Weiner et al., 1976; Westbroek et al., 1979; Lowenstein, 1981; Ourisson and Nakatani, 1994; Waggoner, 2002; Schweitzer, 2003; Pääbo et al., 2004; Asara et al., 2007), provided that the specimens were excavated and stored in a suitable manner (cf. Pruvost et al., 2007).

Unfortunately, chemical analyses generally consume the specimens or parts thereof, thus reducing the morphological information they contain (Albrecht and Ourisson, 1971;

Published by Copernicus Publications on behalf of the European Geosciences Union. 
Sælen, 1989; Schweitzer et al., 2005; Dunca et al., 2008; Pruvost et al., 2007; Asara et al., 2007). While a number of techniques exist that can non-destructively image the surface of a specimen (see, e.g., Sælen, 1989; Scott and Collinson, 2003), serial grinding techniques combined with digital photography have long been the only method allowing to reconstruct the three-dimensional structure of fossils at a high spatial resolution (Luo and Eastman, 1995; Luo and Marsh, 1996; Sutton et al., 2001; Siveter et al., 2004; Sutton et al., 2005), yet they trade this achievement for a complete loss of the specimen. Due to these technical limitations, obtaining chemical and morphological information from within fossils has generally been mutually exclusive but progress in non-invasive imaging techniques of geomaterials in general has important spill-over effects for palaeontological investigations (Rothwell and Vinegar, 1985; Carlson, 2006).

One non-destructive approach to construct 3-D representations of porous or otherwise heterogeneous materials at microscopic resolution is x-ray Computed Tomography (CT) which enjoys considerable popularity for fossil analysis (for an overview, see Zollikofer and Ponce de Léon, 2005) and can still be enhanced by monochromatisation, leading to synchrotron radiation CT (SR-CT; cf. Tafforeau et al., 2006; Mazurier et al., 2006; Donoghue et al., 2006).

Two other tomographic techniques have recently been demonstrated to allow for non-invasive in saxo imaging (from Latin saxum, rock) of three-dimensional fossil morphologies: Neutron Tomography (NT; cf. Domanus, 1992) has successfully been used to acquire images of sauropod vertebrae (Schwarz et al., 2005), while Magnetic Resonance Imaging (MRI; for detailed description, see Callaghan, 1991) can either be used to generate negative images of mouldic or cavernous fossil samples by immersing them in or filling them with materials that provide MR signal (e.g. water or oil, possibly containing contrast agents; Sebes et al., 1991; Steiger et al., 1997; de Swiet et al., 1998; Steiger, 2001; Clark et al., 2004), or the fossil morphology can be imaged directly, solely on the basis of intrinsic contrast, as shown for pathological belemnite rostra (Mietchen et al., 2005). Like CT, both NT and MRI can reach microscopic resolutions, and for all three tomographic modalities, spectroscopic sister techniques exist that allow a detailed chemical characterisation of a given specimen (Boyce et al., 2002; Gabel et al., 2002; Abragam, 1961).

In this study, we concentrated on in saxo MRI whose signal intensity had been found to co-vary with pathological alterations of biomineralisation in the belemnite specimens mentioned above. Specifically, we addressed the issue whether the method would equally be applicable to nonpathological rostra and to fossils other than belemnites - as previous studies of fluids in porous rocks (de Swiet et al., 1998) and of extant biomineralised samples (Majumdar et al., 1998; Borah et al., 2001; Tsai et al., 2004; Müller et al., 2006) would suggest - and used MRI to investigate the internal morphology of non-pathological fossils of invertebrate, ver- tebrate and plant origins from different geological settings.

The fossil material figured here is housed at the Museum für Naturkunde der Humboldt-Universität zu Berlin, Germany (acronym MB.) and in the Museum für Natur und Umwelt in Lübeck, Germany (acronym MNU).

\section{Diagenesis of biomineralised structures}

When considering the use of new methodologies like MRI for the structural investigation of fossils, it is necessary to reflect on the material characteristics of the skeleton, the extent to which the original morphologic structures have been diagenetically altered and how this could affect the acquisition and interpretation of the data. The following sections will hence review biomineralisation and diagenetic processes in selected taxonomic groups, with a focus on preservation of organic matter in the mineral matrix (the preservation of water will be discussed in Sect. 5.4). Several reviews are available that treat taphonomy, particularly chemical and microbial degradation of the organic and mineral fractions, in more detail (Behrensmeyer, 1978; Behrensmeyer et al., 2000; Collins et al., 2002; Dauphin, 2002; Kidwell and Holland, 2002; Briggs, 2003).

\subsection{Invertebrates}

\subsubsection{Overview}

Shells of macroinvertebrates composed of calcium carbonate abound in the Phanerozoic fossil record. Calcite is the more stable crystal form, though shells composed thereof may have experienced diagenetic recrystallisation. Aragonitic shells have commonly been dissolved during diagenesis or replaced by other minerals, mainly calcite. The organic matrix has been attributed several functions in biomineralisation, including nucleation of the mineral, determination of the mineral phase, control of the orientation and growth of carbonate crystals, and enhancement of mechanical properties of the crystals (e.g. Crenshaw, 1990). Biochemically, it consists of proteins, poly-saccharides, and water. A major portion of the soluble fraction of organic matrix macromolecules are aspartic acid-rich glycoproteins, whereas important constituents of the insoluble fraction are glycine, alanine and chitin (for details, see Lowenstam and Weiner, 1989).

The properties of organic matrix components are subject to often severe postmortem alterations - proteins, for instance, decompose to individual amino acids which can undergo isomerisation and further decomposition down to simple hydrocarbons (Collins and Gernaey-Child, 2001). Several studies have documented the presence of amino acids in fossil shells as old as about $360 \mathrm{Ma}$ (summarised in Weiner, 1979). However, the amino acid composition of a Late Cretaceous (80 Ma before present) ammonoid shell bore no resemblance 
to that found in a close extant relative, the cephalopod $\mathrm{Nau}$ tilus (Weiner, 1979).

\subsubsection{Belemnites}

Another group of cephalopods, now extinct, are the belemnites. They had an endoskeleton whose most distal part - the rostrum or guard that helped to maintain a horizontal swimming posture (Naef, 1922) - is frequently preserved. It consists of the rostrum cavum with the alveolus - a conical cavity at its anterior end - and the rostrum solidum (e.g. Sælen, 1989, cf. Fig. 1). It is further characterised by (1) the apical line, which represents the axis of the rostrum and marks the trajectory of the apex (the most posterior part of the rostrum) during successive growth stages, (2) composite radial structures formed by crystals radiating out from the apical line to the margin and (3) commarginal (concentric) growth lines (also known as growth rings) which stem from periodical accretions of radial structures that resulted in spatial variations of the organic content. This variation is often subtle, so that growth rings may be difficult to define (Sælen, 1989).

Apart from the primordial rostrum and very early growth stages, the original mineralogy of belemnite rostra was lowMg calcite (Veizer, 1974). As such they are relatively stable even under freshwater influence (meteoric diagenesis). The microstructure consists of regular, fine prisms with parallel crystal axes, arranged in well-ordered prismatic layers (Bandel and Spaeth, 1988) which can still be discerned in even strongly recrystallised specimens. Diagenetic exchange between rostra and enclosing rock appears to be limited (up to about $10 \%$ by weight, according to Veizer, 1974) and may be caused by solution-precipitation phenomena or filling of the pore space. The latter was either primary or diagenetically generated by the decay of organic matter. Growth lines are frequently preserved.

With respect to organic matrix macromolecules in belemnites, Westbroek et al. (1979) analysed rostra of two late Cretaceous taxa, Gonioteuthis and Belemnitella. In the soluble macromolecular fraction of well-preserved Gonioteuthis rostra, these authors identified components with peptidic and saccharidic properties as well as an amino acid composition very similar to that of Nautilus, dominated by glycine and alanine. Even original antigenic properties of certain fractions were still preserved, suggesting that the biochemical materials derived from Gonioteuthis were original belemnite compounds which only experienced minor alterations during diagenesis. The observed enrichment in polyphenols may be due to reactions between peptides and carbohydrates during diagenesis. In contrast to the exceptionally well-preserved rostra of Gonioteuthis, those of Belemnitella were strongly recrystallised. Although the amino acid composition is similarly dominated by glycine $(12.6 \mathrm{~mol} \%)$ and alanine (11.5 mol\%), less stable (threonine, serine, arginine $-5.5,6.2$ and $4.9 \mathrm{~mol} \%$, respectively) and even very labile amino acids (methionine, $2.2 \mathrm{~mol} \%$ ) were also present.

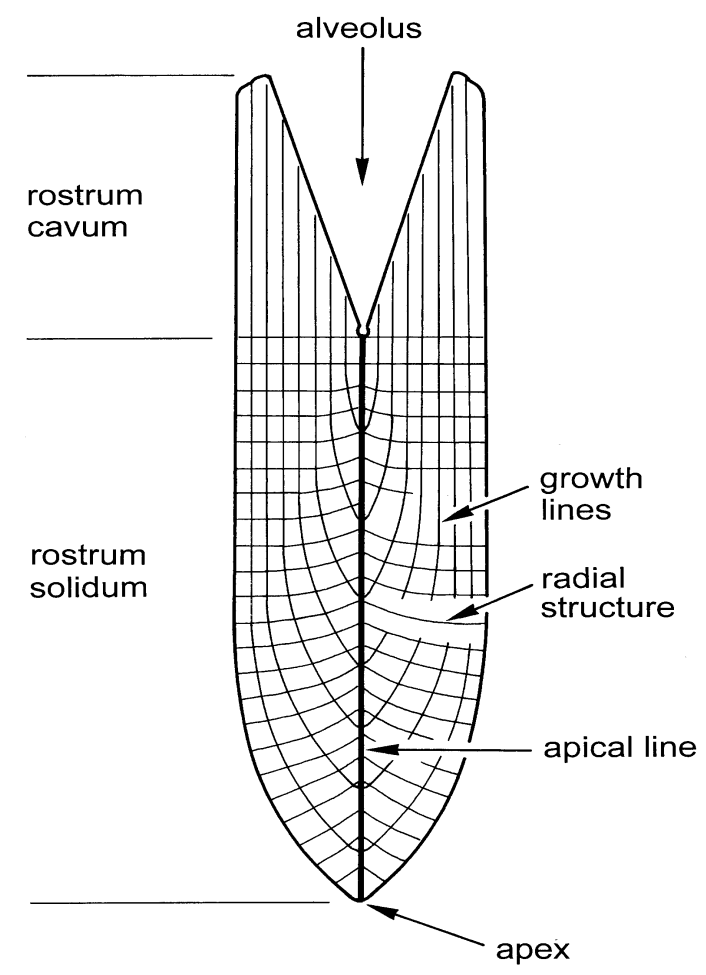

Fig. 1. Schematic sketch of the anatomy of a belemnite guard (longitudinal section), showing the proximal rostrum cavum, the distal rostrum solidum and the apical line (also known as central channel).

Westbroek et al. concluded thus that the primary organic composition of the Belemnitella rostra was contaminated during or after recrystallisation by percolating ground water.

\subsubsection{Crinoids}

As in all echinoderms, the crinoid stalk ossicles belong to the mesodermal endoskeleton and are composed of magnesium calcite which is arranged in the typical form of a stereom (a meshwork of anastomosing trabeculae and pillars). In the living crinoid, the interspace in the stereom is filled with soma which contains living cells, mainly sclerocytes and phagocytes (Heinzeller and Welsch, 1994). Columnals bearing cirri are nodals, those without cirri are internodals. Connections of the ossicles are nonmuscular and exclusively by elastic ligaments of mutable collagenous tissue. Short, intercolumnar ligaments connect each pair of adjacent columnals. Longer, continuous ligaments connect each set of internodals and one associated nodal (Ausich et al., 1999).

Columnals of Isselicrinus buchii are cylindrical, rarely subpentagonal, with a smooth surface. The corresponding articulations of adjacent ossicles bear a characteristic pattern: Interlocking grooves and ridges of densified stereom occur in a petaloid pattern, giving the stem a certain flexibility. A crenulation is also visible at the margin of most ossicles, and 
the stem possesses a small central canal which represents a tubular cavity with extensions of the coelom and nervous system (Ausich et al., 1999).

Skeletal particles of echinoderms are usually preserved as large single crystals of calcite. During diagenesis, the metastable high Mg-calcite of the echinoderm skeleton is replaced by low $\mathrm{Mg}$-calcite. This transformation occurs by means of a solid-state process known as incongruent dissolution. Unidirectional growth of calcite crystals gives rise to syntaxial cements, the formation of which starts with the infilling of the pore space. Occasionally, the microstructure may be preserved when the porespace is infilled with clay preventing precipitation of spar. Even more rarely, the echinoderm crystals can be diagenetically transformed into microcristalline calcite (also known as micrite; Neugebauer, 1978). Under favourable conditions (rapid burial, low pore water circulation, an- or dysoxic conditions), organic remains such as color pigments can be preserved within the stereom (Blumer, 1965; Wolkenstein et al., 2006). Especially in the Cretaceous chalk sea, dissolution or corrosion of echinodermal magnesium calcite occured either on the sea floor or during diagenesis (Ernst, 1963; Neugebauer, 1978).

\subsection{Vertebrates}

\subsubsection{Overview}

Diagenetic processes acting upon vertebrate remains are far from being completely understood but for most practical purposes, they can be reduced to the diagenesis of bone and its collagenous protein matrix. Although this is still a complex, multistage process, notoriously dependent on external biochemical, hydrological and taphonomical factors of the embedding environment and internal parameters such as bone size, histological structure and collagen content (Martill, 1991; Hedges and Millard, 1995; Schweitzer et al., 2007), it has been relatively well-studied in archaeological sciences, especially in relation to collagen decomposition (NielsenMarsh et al., 2000). Similar to most other proteins, collagen is composed mostly of carbon, hydrogen, nitrogen and a minor content of sulphur, and its initial decay during early diagenesis is of great importance for the final preservation and chemical composition of the bone (Hedges et al., 1995; Nielsen-Marsh and Hedges, 2000; Pfretzschner, 1998, 2000; Schweitzer et al., 2005, 2007). Generally, microbial degradation of collagen accelerates destruction (Collins et al., 1995) and therefore hinders fossil preservation of bone. However, microbial activity depends on a number of chemical parameters - including temperature, $\mathrm{pH}$ and the availability of oxygen and water - whose combination might lead to reduced microbial degradation (Bocherens et al., 1997; Nielsen-Marsh and Hedges, 2000), which is an advantage for later fossilisation. The proteolysis of collagen, especially under water, is determined by local $\mathrm{pH}$ as well as the redox potential of bone during early diagenesis (Pfretzschner,
1998), and this influences the ion and isotope exchange rates between the phosphorous mineral phase of the skeletal remains and the ambient fluid and sediment. Reaction conditions, moreover, differ between freshwater and marine environments. Finally, even if two samples have been taken from the same fossil specimen, the circumstances of their excavation, handling, storage and analysis can severely influence the residual biochemical information contained therein, as has been shown for DNA contents (Pruvost et al., 2007) but can be assumed to be the case for other macromolecules and water as well.

\subsubsection{Bone preservation and taphonomy}

Bone material consists of the biomineral hydroxy apatite $\mathrm{Ca}_{5}\left(\mathrm{PO}_{4}\right)_{3} \mathrm{OH}$ - which can be modified during fossilisation by various chemical interactions with the environment and the sediment covering the carcass (Rottländer, 1979). Depending on the environmental distribution of reactants (Pfretzschner, 1998), the mobile ions within the apatite crystal $-\mathrm{H}^{+}, \mathrm{Ca}^{2+}, \mathrm{HPO}_{4}^{2-}$ and $\mathrm{OH}^{-}$- can be substituted, as Piepenbrink (1989) has shown for subfossil human bone. $\mathrm{Ca}^{2+}$, for example, is often replaced by $\mathrm{UO}_{2}^{2+}$ (Millard and Hedges, 1995; Pfretzschner, 1997) or $\mathrm{Sr}^{2+}$, or $2 \mathrm{Ca}^{2+}$ by $\mathrm{Na}^{+}$and $\mathrm{Y}^{3+}$. Likewise, the phosphate group $\mathrm{HPO}_{4}^{2-}$ can exchange with $\mathrm{SO}_{4}^{2-}$ or $\mathrm{CO}_{3}^{2-} . \mathrm{SiO}_{2}, \mathrm{~V}^{4+}$ or $\mathrm{As}^{3+}$ can also move into the crystal lattice, while $\mathrm{F}^{-}$and $\mathrm{Cl}^{-}$can substitute for $\mathrm{OH}^{-}$(Newesely, 1989; Pfretzschner, 2000; Trueman, 1999). The histological structure of bone is important for the interaction with the ambient fluid. The pore structure, which often follows a trajectory pre-defined by in vivo biomechanical load, determines the internal surface area and therefore the capacity for surface reactions (Hedges and Millard, 1995).

\subsubsection{Fossil ear bones}

With the exception of some phylogenetically early species (cf. Luo et al., 2007), the mammalian ear bones typically comprise the tympanic bulla, the middle ear with the three ossicles malleus, incus and stapes, and the periotic bone with the cochlear portion containing the spiral cavity which forms the organ of sound reception (Berta and Sumich, 1999). The cochlea is coiled and divided lengthwise into three parallel tubular channels (Liem et al., 2001, Fig. 12-22).

In cetaceans, the periotic is the most compact skull bone and of a comparatively stable and chemically resistent nature. As an adaptation to underwater hearing, it is displaced from the skull by pneumatic spaces (e.g. Purves and Pilleri, 1983 ) and only loosely connected to it via ligaments to the mastoid process (Pilleri et al., 1987). The detachment allows separate reception of sound and isolated vibrations of the ear bones (Miller, 1923; Fleischer, 1978; Pilleri et al., 1987). The anatomy of the cetacean organ of hearing is well described (Pilleri et al., 1987) but was usually studied by 
producing serial sections by grinding the petrosals (e.g. Luo and Eastman, 1995; Luo and Marsh, 1996), resulting in the loss of the unique fossil specimens. Petrosals obtained from contemporary animals (e.g. Ketten and Wartzok, 1990; Nummela et al., 1999) have successfully been imaged by CT, as have fossil cetacean petrosals (Spoor et al., 2002) and entire fossil cetacean skulls (at resolutions not suitable for petrosal investigations, cf. Marino et al., 2003).

Incidentally, the first MR imaging of fossils that we know of (Sebes et al., 1991) has been performed on the vertebrae of a Miocene dolphin, though the specimen was immersed in water which provided the contrast. The species was not mentioned in that report but determined as Xiphiacetus bossi (Kellogg) USNM 10480 (D. Bohaska and B. Rothschild, personal communication). At the time of writing, it was not known whether the water immersion had had any impact on the state of preservation of these vertebrae, as compared to non-immersed vertebrae of the same specimen.

\subsection{Plants}

Petrified plant remains, mainly silicified wood, are a frequent feature in the fossil record. In ion exchange reactions similar to those desribed above for bone, silica minerals are deposited in cracks, openings between cells, and spaces left by cell fluids. These processes take place while the wood is still relatively intact. Consequently, petrified plant parts exhibit preserved morphological patterns down to the cellular scale, and they often contain organic and carbon compounds. Silicification depends on the thermal conditions (Sigleo, 1978) and can occur over a wide $\mathrm{pH}$ range and sometimes very rapidly (in vitro as fast as in $24 \mathrm{~h}$, according to Drum, 1968). The most probable mechanism for wood silicification is hydrogen bonding between silicic acid, $\mathrm{Si}(\mathrm{OH})_{4}$, and the hydroxyl groups in cellulose. When studying Araucarioxylon arizonicum fossils from the Triassic Chinle Formation of Petrified Forest National Park in Arizona for lignin derivates, Sigleo (1978) was able to identify various organic compounds in silicified wood by sequential high vacuum pyrolysis, gas chromatography and mass spectrometry. These organic components included phenols, methylphenols, alkyl substituted benzenes and benzofurans. Further support for organic remains in plant fossils comes from elemental mapping of silicified wood from Palaeozoic up to Miocene sites (Boyce et al., 2001), and Siurek et al. (2004) - who investigated silicified wood from Chile and the Barton Peninsula (King George Island, Antarctica) - found carbon in each volume element they tested, in most cases convincingly attributable to the remnant primary organic matter.

As for noninvasive imaging, $\mathrm{x}$-ray tomography was applied successfully to pyritized fossil fruits from the Lower Eocene London Clay flora, namely to the visualisation of internal structures, including small seeds, within Myrtaceaen fruits (DeVore et al., 2006), and further applications are about to emerge, e.g. for the study of internal structures (down to the cellular level) within charcoalified three-dimensionally preserved Cretaceous flowers (Friis et al., 2006). MR imaging has, however, found multiple applications to extant plant specimens (Chudek and Hunter, 1997), including conifer cones (e.g. Mill et al., 2001).

\section{Specimen description}

\subsection{Invertebrates}

\subsubsection{Belemnites}

The analysed belemnite rostra, identified as Belemnopsis sp. by Dietrich (1933), were collected by the German Tendaguru Expedition (1909-1912, cf. Janensch, 1914). The fossil locality of Tendaguru, famous for its diverse dinosaur assemblages, is located approximately $60 \mathrm{~km}$ northwest of the seaport of Lindi in southeastern Tanzania. The Late Jurassic to Early Cretaceous (ca. 155-130 Ma before present) Tendaguru Beds reach a thickness of $110 \mathrm{~m}$ and consist of three fine-grained dinosaur-bearing sequences which are intercalated with sandstone-dominated sequences containing a predominantly marine fauna (Aberhan et al., 2002). The rostra were embedded in a medium- to coarse-grained sandstone of Late Jurassic (Tithonian) age at the transition between the so-called Trigonia smeei Bed and the base of the Upper Saurian Bed at Tendaguru site IX, about $1.4 \mathrm{~km}$ northeast of Tendaguru Hill. Most specimens are fragmented and the outer surface appears pitted due to intense weathering. Recent sedimentological and palaeoecological analyses of the Tendaguru Beds (Aberhan et al., 2002) suggest that deposition of the Trigonia smeei Bed took place in lagoon-like, shallow marine environments above fair weather wave base and with evidence of tides and storms. Sediments of the Upper Saurian Bed represent extended siliciclastic tidal flat environments including brackish coastal lakes and ponds. The Late Jurassic palaeoclimate of the Tendaguru area was subtropical to tropical, characterised by seasonal rainfall alternating with a pronounced dry season.

The analysed rostrum of Belemnella (Pachybelemnella) sumensis Jeletzky is from the boreal Upper Cretaceous (Lower Maastrichtian, ca. 69 Ma before present) white chalk of the Stubbenkammer, Isle of Rügen (Northeastern Germany). The sedimentary matrix is a weakly lithified coccolith limestone, representing fully marine, distal open shelf conditions well below storm wave base.

\subsubsection{Crinoids}

The crinoid specimen (MNHB/MB.E 5730) used for this study belongs to the species Isselicrinus buchii Roemer and was found together with the above-described Belemnella (Pachybelemnella) sumensis sample in the white chalk of Stubbenkammer, Isle of Rügen, Germany. Isselicrinus buchii is the most abundant crinoid taxon of the chalk soft bottom 
ecosystem during the Maastrichtian. As a stalked crinoid, Isselicrinus was highly adapted for a life on a muddy substrate. It possessed a relay strategy, using pre-existing upright stem columns as anchorage (Fujiwara et al., 2004). The long stem raised the cup highly above the sea floor into the water current. As a passive suspension feeder, this crinoid was dependent on currents transporting plankton to the catch apparatus formed by the crinoid's arms (Oji, 1985, 1990). We used only columnals (stem elements) for MR imaging.

\subsection{Vertebrates}

The bone used for the current study was a periotic originating from a partial skeleton of a kentriodontid dolphin (Cetacea: Odontoceti) belonging to the genus Atocetus de Muizon of the subfamily Pithanodelphininae Barnes. This Atocetus fossil was discovered in a commercial gravel pit near Groß Pampau in Schleswig-Holstein, northern Germany, and is stored since then in the Museum für Natur und Umwelt in Lübeck (MNU-071-18). The site is famous for several whale remains (e.g. Höpfner, 1991; Hampe, 1999). The horizon containing the whale fossils belonged to a dark mica clay ("Oberer Glimmerton" in regional stratigraphy; cf. Hinsch, 1990) that was deposited between 10.6 Ma and 11.8 Ma (Spiegler and Gürs, 1996) after Bolboforma biozones (around the middle/upper Miocene boundary) and is rich in organic matter, the sheet silicate muscovite and occasionally in pyrite, glauconite, and carbonate (Gripp, 1964).

\subsection{Plants}

Two silicified fossils were chosen that revealed anatomical details under the light microscope. They had been collected in 1937 by M. Wehrfeld at the "classic" locality Cerro Cuadrado in North Patagonia, Argentina, and were later donated to W. Gothan (cf. Gothan, 1950). At this site (comprehensively described by Dernbach et al., 1992), silicified conifer remains are preserved in a volcanic ash considered to be mid- to late Jurassic (ca. 150-160 Ma; Calder, 1953; Menéndez, 1960).

MB.Pb. 2006/511 is a silicified twig of about $9 \mathrm{~cm}$ length and approximately $1.3 \mathrm{~cm}$ diameter from an araucarian conifer and appears poorly preserved. The piece is broken off at the base and at the top. The Brachyphyllum-type foliage is dense and seems to be helically arranged. The leaves show rhomboidal leaf cushions and acute apices. In most cases, only the leaf base is preserved, and no obvious wood or leaf structures are visible under the light microscope.

The second piece (MB.Pb. 2006/512), a cone of a conifer of uncertain affinities, Pararaucaria patagonica Wieland, is approximately $3.3 \mathrm{~cm}$ in length and $1.5 \mathrm{~cm}$ in maximal diameter and exhibits a good three-dimensional preservation under the microscope (cf. Fig. 5a). Such cones have previously been described in detail (e.g. Stockey, 1977), and this exemplar belongs to a group of three specimens in the Museum's collection that had already partly been sectioned horizontally and vertically (MB.Pb. 2004/948), which provided for comparisons with the MR images. These cones are completely silicified by alpha-quartz (Stockey, 1975) which is also known as chalcedony and can vary in colour between seeds (Darrow, 1936). Finally, abundantly interspersed haematite renders the fossils reddish brown.

\section{Magnetic Resonance Imaging and Spectroscopy}

As for MR imaging, the same methodology as in Mietchen et al. (2005) was employed. The MRI experiments were thus performed on a Bruker Avance NMR spectrometer (Bruker, Rheinstetten, Germany) operating at a ${ }^{1} \mathrm{H}$ resonance frequency of $400 \mathrm{MHz}$ with standard Micro2.5 microimaging equipment and a maximum gradient strength of $0.95 \mathrm{~T} / \mathrm{m}$.

Typical images were recorded using a standard 3D spinecho imaging sequence (for details, see Ernst et al., 1997) with a Field of view (FOV) of $15 \times 15 \times 30 \mathrm{~mm}^{3}$, a matrix size (MTX) of $128 \times 128 \times 256$ voxels, an echo time $T_{E}=1.3 \mathrm{~ms}$, a repetition time $T_{R}=1 \mathrm{~s}$, giving an isotropic voxel resolution of $80 \mu \mathrm{m}$ (note that resolution in the different directions can be handled independently). With number of averages $\left(N_{A}\right)=2$, this results in a total experimental time $\left(T_{\exp }\right)$ of $18 \mathrm{~h}$. The maximum gradient used for MR imaging was $0.95 \mathrm{~T} / \mathrm{m}$. Deviations from this parameter set are given in the figure captions. All measurements were performed at a temperature of $(22 \pm 1)^{\circ} \mathrm{C}$ if not mentioned otherwise. The images were visualised and processed with the help of ImageJ (developed at the National Institutes of Health and available online via http://rsb.info.nih.gov/ij/).

Magic Angle Spinning (MAS) is a variant of MR spectroscopy in which the sample is quickly spun around an axis inclined to the static magnetic field, such that anisotropic interactions between MR-sensitive nuclei average out (reviewed in Andrew, 1981; Garroway et al., 1981; Veeman, 1997). For MAS NMR spectroscopy, the powdered sample was placed inside a standard $\mathrm{ZrO}_{2}$ MAS rotor of $4 \mathrm{~mm}$ outer diameter. The data were acquired at a spinning speed of $10 \mathrm{kHz}$ and a repetition time of $3 \mathrm{~s}$. For the ${ }^{1} \mathrm{H}$ spectra, 32 transients were averaged, and 22200 for the ${ }^{13} \mathrm{C}$ spectra.

\section{Results and discussion}

\subsection{Invertebrates}

\subsubsection{Belemnites}

In cross-sectional MR images of the Belemnopsis samples (cf. Fig. 2c, e), concentric circles reflecting radially oscillating signal intensity can easily be identified - with higher signal intensity indicating a higher number of mobile ${ }^{1} \mathrm{H}$ nuclei, and lower signal indicating lower ${ }^{1} \mathrm{H}$ contents, lower 
mobility or a combination of both. As for the molecular affiliation of these nuclei (see also Sect. 5.4), water would perhaps provide the most parsimonious explanation but organic remains of the original material would also be compatible with recently published findings (Florek et al., 2004): organic and inorganic signals in electron microprobe measurements showed very similar oscillatory patterns in belemnite rostra, yet with opposite sign, along a radial line extending from the central channel. The signal oscillations correspond to growth rings reflecting a layered microstructure similar to the one described for nacre (Jackson et al., 1988; Feng et al., 1999, 2000), where inorganic layers (aragonite in bivalves, calcite in belemnites) basically alternate with organic layers, with each of both phases forming a continuum through small bridges (cf. Fig. 10ff in Jackson et al., 1988). The latter, however, can not be identified in our MRI data. In the longitudinal sections, the apical line or central channel is marked by low signal intensities over its entire preserved length, from the apex to the alveolus at the distal tip of the phragmocone. Interestingly, the apical line is marked by high signal intensity in the otherwise rather featureless Belemnella sample (cf. Fig. 2d, f), thereby effectively reversing the image contrast with respect to the Belemnopsis guard.

\subsubsection{Crinoids}

Figure 3 depicts MR images obtained from the Isselicrinus columnals from Rügen (MNHB/MB.E 5730). Visible are the small central canal and the grooves and ridges serving as attachment surfaces for connective ligaments as well as crenellae along the margin. The spatial resolution achieved with this sample was $108 \mu \mathrm{m}$ in the image plane depicted here (subsequently, it was artificially increased by a factor of two via zerofilling of the data set before Fourier transformation) and $50 \mu \mathrm{m}$ perpendicular to it - the highest resolution achieved in the MR images described in this study.

\subsection{Vertebrates}

The MR images of the whale periotics (cf. Fig. 4) reveal a strong signal in the posterior cochlear part and the posterior process of the bone. At the site of Groß Pampau, the fossil bones are associated with diagenetically produced minerals like glauconite and pyrite. The latter is a product of a reaction between iron (from sediment or haemoglobin degradation) and sulphur $\left(\mathrm{H}_{2} \mathrm{~S}\right.$ released by protein degradation, $\mathrm{cf}$. Pfretzschner, 2000). $\mathrm{FeS}_{2}$ (pyrite) develops under alkaline conditions, e.g. in the presence of water-dissolved $\mathrm{NH}_{3}$ produced during collagen decay. The chemical history of the hydrogen and carbon of the decomposed protein is less clear. It appears possible, though, that part of these molecules still reside in the bone and contribute to the high signal intensity.

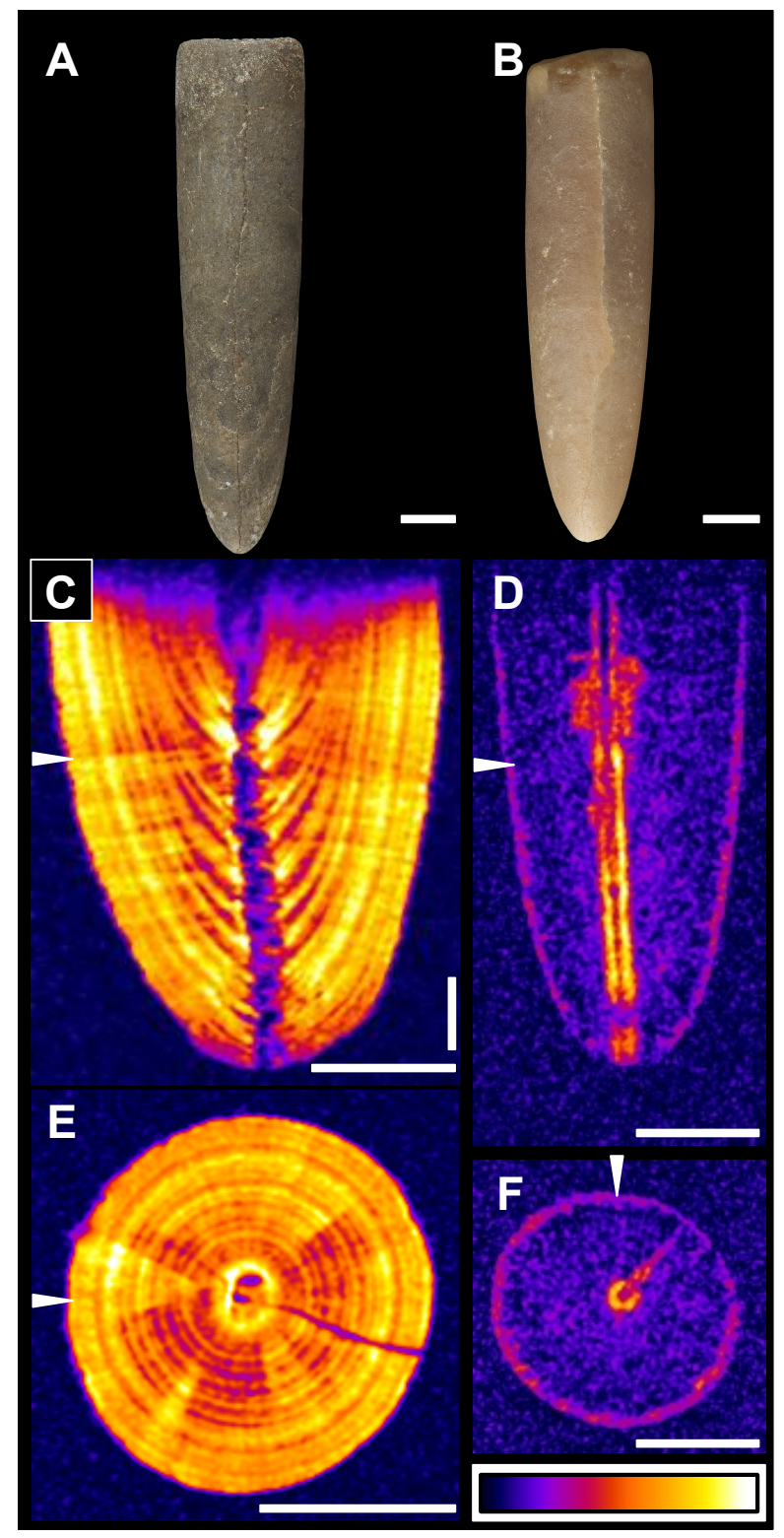

Fig. 2. Three-dimensional MR imaging of two belemnite guards of different origin: Belemnopsis sp. (MB.C. 3701.3) from Tendaguru, site IX (A, C, E) and Belemnella (Pachybelemnella) sumensis Jeletzky (MB.C. 3884) from Rügen (B, D, F). (A, B): Longitudinal view (photomocrographs). Scale bars throughout this paper are isotropic $5 \mathrm{~mm}$ or otherwise $5 \mathrm{~mm}$ in the indicated directions. (C, D) Longitudinal MR image slices. (C) MTX: $(256 \mathrm{pxl})^{3}, T_{R}=784 \mathrm{~ms}$, $N_{A}=8, T_{\exp }=113 \mathrm{~h}$. For further details, see Sect. 4 in text. Arrow heads in (C) and (D) indicate slice positions in $(\mathrm{E})$ and $(\mathrm{F})$, and vice versa. (D) FOV: $12 \times 12 \times 30 \mathrm{~mm}^{3}$. (E, F) Transverse sections. The colour scale (identical for all MR images presented in here) represents MR signal intensity in arbitrary units, white is maximum. 3-D slice series oriented as in (D) and (E) are given as Movies 1 and 2 (http://www.biogeosciences.net/5/25/2008/ bg-5-25-2008-supplement.zip) (in steps of $94 \mu \mathrm{m}$ and $117 \mu \mathrm{m}$, respectively). 


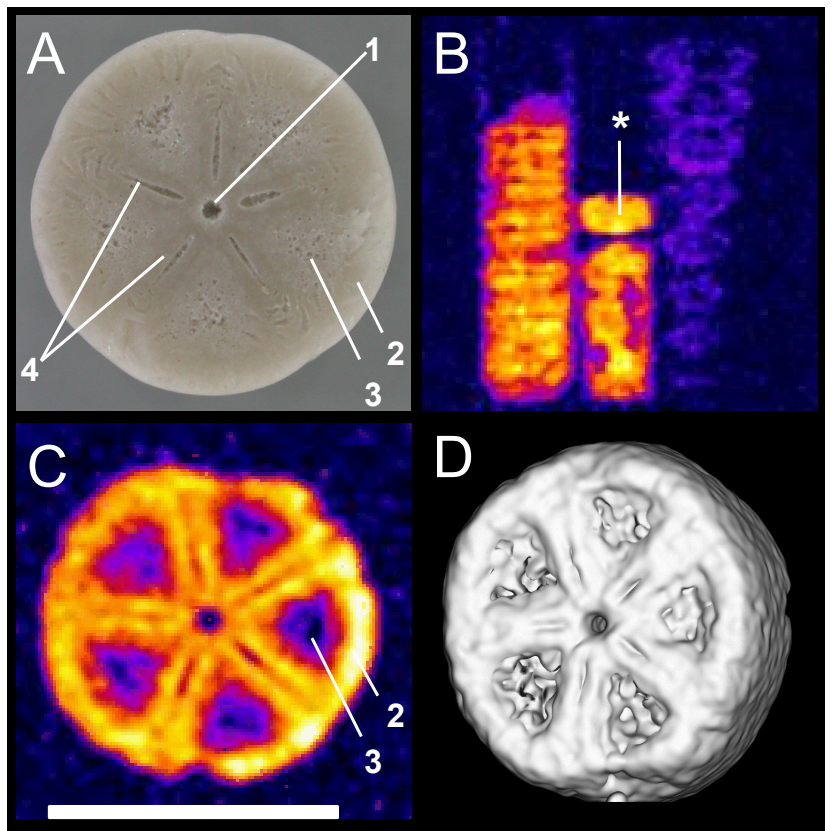

Fig. 3. Four different views at a fossil crinoid (Isselicrinus buchii) from Rügen, Germany (MNHB/MB.E 5730). (A) lateral view (photomicrograph). 1, central canal; 2, peripheral crenellae; 3, groove (or interradial petal); 4, adradial ridges. (B) MR image slice from MNHB/MB.E 5730 (denoted by asterisque) and other fossil crinoids from Rügen (MNHB/MB.E 6300). FOV: $(15 \mathrm{~mm})^{3}$, MTX: $(128 \mathrm{pxl})^{3}, T_{R}: 877 \mathrm{~ms}, N_{A}: 4, T_{\exp }: 16 \mathrm{~h}$. (C) High-resolution MR image slice of MNHB/MB.E 5730 . FOV: $6.9 \times 6.9 \times 3.2 \mathrm{~mm}^{3}$, MTX: $(64 \mathrm{pxl})^{3}$ (here zero-filled to an isotropic matrix of $128 \mathrm{pxl}$ ), $T_{R}: 2.9 \mathrm{~s}, N_{A}: 32, T_{\exp }: 106 \mathrm{~h}$. The corresponding original image slice series (in steps of $50 \mu \mathrm{m}$ ) is supplied as Movie 3 (http://www. biogeosciences.net/5/25/2008/bg-5-25-2008-supplement.zip). (D) 3-D rendering of the dataset shown in (C) and Movie 3. The surface is defined by pixels with at least $50 \%$ of the maximal signal intensity.

\subsection{Plants}

In the MR image depicted in Fig. 5b, several anatomical details of the fir cone (MB.Pb. 2006/512) are visible: The cone axis is situated in the centre, surrounded by scales. The embedded seeds on each ovuliferous scale show a high signal intensity. This even allows to discern seed-internal patterns, though it remains unclear whether these reflect part of the former biological structures (like seed integuments or embryos) or diagenetic alterations thereof.

The MR images (not shown) obtained from the Jurassic araucarian twig (MB.Pb. 2006/511) exhibited a much lower overall signal intensity than the Pararaucaria cone. One possible explanation for this could be long-term waterlogging, by means of which the original organic matter would already have been decayed to a high degree before the onset of silicification - it is known that the physical appearance of fos- (a)

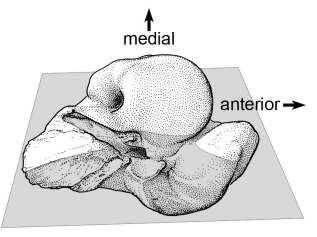

(b)

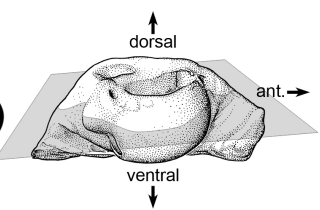

(c)

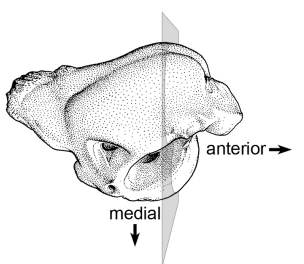

(d)

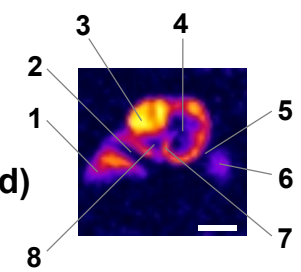

(e)

9

(f)

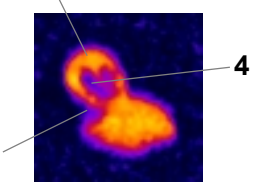

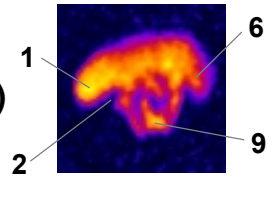

Fig. 4. Fossil left periotic (MNU 071-18) of Atocetus sp. (Cetacea) in (A) ventral/tympanal view; (B) medial view; (C) dorsal/cerebral view, showing the level of the corresponding MR sections to the right. (D) MR diagonal section; (E) MR horizontal section; (F) MR vertical section. 1, posterior process; 2 , canal for facial nerve; 3 , useful site for future analyses of signal origin; 4 , inner auditory passage; 5 , groove for tensor tympani; 6 , anterior process; 7 , transversal septum; 8 , fenestra rotunda; 9 , cochlea. MR parameters: FOV: $22 \times 22 \times 22 \mathrm{~mm}^{3}$, MTX: $64 \times 64 \times 64 \mathrm{pxl}^{3}, \mathrm{~T}_{E}: 0.6 \mathrm{~ms}, N_{A}: 32$, $\mathrm{T}_{\mathrm{exp}}: 36 \mathrm{~h}$. The corresponding original image slice series (in steps of $344 \mu \mathrm{m}$ ) is supplied as Movie 4 (http://www.biogeosciences.net/ 5/25/2008/bg-5-25-2008-supplement.zip). The image plane runs from ventro-lateral to dorso-medial, starting at the anterior process, passing the groove for tensor tympani, which divides in the movie the anterior (top) from the posterior half (bottom) of the periotic, followed by the appearance of the cochlea (left) with its coiled inner auditory canal (labyrinth). Subsequently, the canal for the facial nerve appears below the cochlea in a "slash-like" manner. The movie ends with the sigmoidally shaped tympanic canal (scala tympani) which opens into the fenestra rotunda (bottom).

sil conifer remains is a function of the residence time either in a terrestrial or aquatic setting (Gastaldo, 1991). Experiments on extant leaf litter have demonstrated degradation in floating plant material: The breakdown starts already with the leaching of water-soluble substances and is accelerated by higher water temperatures. This phase is followed by invasion of micro-organisms, mainly fungi and bacteria (Ferguson, 1985). The fossil conifer twig used for this study has most likely undergone both types of degradation while floating in the water column, perhaps for as long as several months. If the different fossilisation history of the cone, on the other hand, led to a complete silicification shortly after abscission from the tree, it would appear plausible that some organic compounds might still be in place and possibly con- 


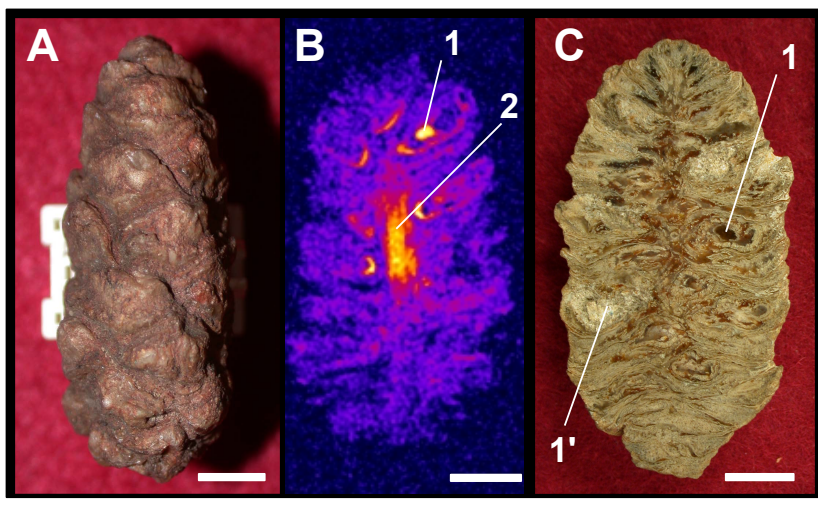

Fig. 5. MR imaging of fossil cones of the conifer Pararaucaria patagonica. (A) Surface view of an ovulate cone (MB.Pb. 2006/512; Coll. Wehrfeld 1937) with cone scales (photomicrograph). (B) Cross-sectional MR image of the same sample. FOV: $17 \times 17 \times 34 \mathrm{~mm}^{3}, N_{A}: 12, T_{\text {exp }}$ : $109 \mathrm{~h}$. The original image slice series (oriented as here, in steps of $133 \mu \mathrm{m}$ ) is supplied as Movie 5 (http://www.biogeosciences.net/5/25/2008/ bg-5-25-2008-supplement.zip). 1, seed; 2, axis. (C) Longitudinal section (photomicrograph) of a similar ovulate cone (MB.Pb. 2004/948; Coll. Wehrfeld, 1937) with several helically arranged cone-scale complexes and seeds (1) whose internal structures appear widely destroyed, leaving cavities filled with colourless quartz (1').

tributing to the MR image contrast.

\subsection{Origin of the MR signal}

The molecules that give rise to these signals can be characterised in multiple ways, e.g. by using a Pulsed Gradient Spin Echo MR experiment (Stejskal and Tanner, 1965) which measures their self-diffusion coefficient, an estimate of their translational mobility. The highest self-diffusion coefficients we found in fossil samples (in some belemnites) reached $10^{-11} \mathrm{~m}^{2} \mathrm{~s}^{-1}$, which is comparable to that of water bound to cell membranes (Volke et al., 1994), and more than two orders of magnitude smaller than the $2 \times 10^{-9} \mathrm{~m}^{2} \mathrm{~s}^{-1}$ typically found in free water (Mills, 1973).

In most of the fossils we tested, no translational mobility was detectable. With the given equipment and experimental parameters, it can thus be estimated that the self-diffusion coefficients of the ${ }^{1} \mathrm{H}$-containing molecules within our fossil samples is generally below $10^{-13} \mathrm{~m}^{2} \mathrm{~s}^{-1}$. Interestingly, diffusion determines decay in a recent physical model of kerogenesis (Rothman and Forney, 2007).

The transverse relaxation times $\left(T_{2}\right)$ in the fossil samples ranged in the order of $1 \mathrm{~ms}$, which is three orders below free water but still several orders above those observed in solid crystals (Mansfield, 1965), indicating that the MR-visible molecules retain a certain rotational mobility despite the absence of translational motion. This would be compatible with the idea of organic contributions to the signal, as the oscil-

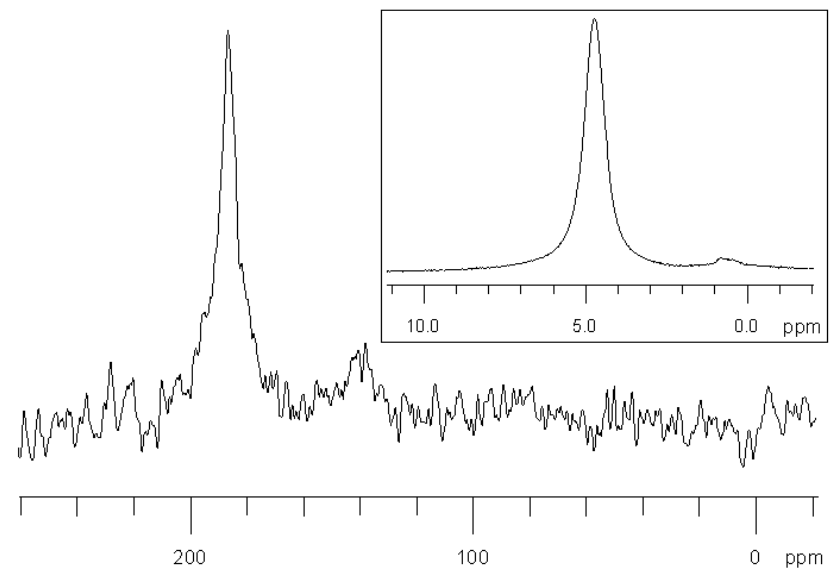

Fig. 6. ${ }^{13} \mathrm{C}$ MAS spectrum of a powder sample obtained from the rostrum of the Tendaguru belemnite (Belemnopsis sp.; MB.C. 3700.11). Inset: Corresponding ${ }^{1} \mathrm{H}$ MAS spectrum. Both spectra were obtained at a spinning frequency of $10 \mathrm{kHz}$ and calibrated against tetramethylsilane, $\mathrm{Si}\left(\mathrm{CH}_{3}\right)_{4}$, in a separate experiment under otherwise identical conditions.

lating biomineralisation patterns described by Florek et al. (2004, see slso Sect. 5.1.1) would suggest.

To further test whether free water contributes to the MR signal, we froze one of the non-pathological Tendaguru belemnites with a self-diffusion coefficient near $10^{-11} \mathrm{~m}^{2} \mathrm{~s}^{-1}$ (Belemnopsis sp.; MB.C. 3700.11) down to $-20^{\circ} \mathrm{C}$, which did not bring about any significant signal change indicative of a phase transition, nor did the signal change when the sample was heated up to $70^{\circ} \mathrm{C}$. We thus heated it in an oven for $8 \mathrm{~h}$ at $200^{\circ} \mathrm{C}$, which did not result in any observable weight loss on a milligram scale, and the MR spectra and images obtained thereafter showed no difference to those obtained before the temperature experiments.

In order to address the issue of the chemical nature of the MR signal in more detail, a piece of this belemnite was powdered and subjected to ${ }^{1} \mathrm{H}$ and ${ }^{13} \mathrm{C}$ NMR MAS spectroscopy. The ${ }^{13} \mathrm{C}$ spectrum (cf. Fig. 6) shows a peak (at about $180 \mathrm{ppm}$ ) reflecting $\mathrm{C}=\mathrm{O}$ or $\mathrm{C}=\mathrm{S}$ double bonds, while no other signal can be clearly identified, and namely no $\mathrm{CH}_{\mathrm{x}}$ groups which would hint at organic material. These observations contrast with ${ }^{13} \mathrm{C}$ MAS spectra previously obtained from fossil pollen or Baltic amber, where $\mathrm{CH}_{\mathrm{x}}$ peaks were readily observable (Hemsley et al., 1995; Lambert et al., 2000) but they fit nicely with the results of organochemical analysis of the belemnite's powder by successive extractions with dichlormethyl/methanol, dichlormethyl/ethanol and ultrasonication - which did not reveal any traces of lipids (P. Albrecht and A. Charrié, personal communication) - and with the finding that total organic contents in (even recent) echinoid calcite was less than $0.2 \mathrm{wt} \%$ (Gaffey, 1995).

The ${ }^{1} \mathrm{H}$ spectrum (cf. inset in Fig. 6), on the other hand, is dominated by the water and hydroxyl peak at $4.8 \mathrm{ppm}$ but 
also shows a small peak between 0 and $1 \mathrm{ppm}$, which is indicative of cyclopropyl, metal-bound methyl groups or mineral hydroxyl groups (Kalinowski et al., 1984; Gaffey, 1995). So, at least in this belemnite, water or hydroxyl groups (the latter perhaps bound to the mineral matrix) seem to have been the major signal contributor to our ${ }^{1} \mathrm{H}$ MR images, and the question about the origin of the signal translates into a question about the origin of these water or hydroxyl groups. We are not aware of any studies focusing on this issue specifically but given that temperature-stable water was found to exist in dental enamel (Myers, 1965, using NMR) as well as in recent and fossil shells (Hudson, 1967, using gas chromatography), it was proposed that hydroxyl groups sometimes take the place of oxygen atoms in the crystal grid (Martin and Donnay, 1972), which has since been affirmed by infrared and NMR techniques (Aines and Rossman, 1984; Gaffey, 1988, 1995; Rossman, 2006). Furthermore, water molecules completely shielded from the bulk of the aqueous solvent have been found in dissolved globular proteins, in the intermolecular interfaces of multimolecular complexes and, notably, in protein crystals (Wider, 1998). Analyses of spots with high signal intensity (e.g. "3" in Fig. 4) could provide further insights into the signal origins in other fossils.

The strong but narrow peak in the ${ }^{1} \mathrm{H}$ spectrum (cf. Fig. 6) can thus perhaps best be explained in terms of rigidly bound $\mathrm{H}_{2} \mathrm{O}$ molecules or $\mathrm{OH}$ groups being close enough to $\mathrm{H}_{2} \mathrm{O}$ molecules in a more liquid state, so as to allow for proton exchange. This fits well with MR spectroscopic observations in echinoid calcite where liquid-like protons were found to amount to about $60 \%$ of the total $\mathrm{H}_{2} \mathrm{O}$ content (Gaffey, 1995). The latter varied around $2-3 \mathrm{wt} \%$, both between individuals and species but even more so between ossicles of the same specimen, which would suggest that total $\mathrm{H}_{2} \mathrm{O}$ might be indicative of ossicle growth or structure (Gaffey, 1995). Nonetheless, a preliminary analysis of MR images and spectra acquired from neo- to palaeolithic mammalian bone and teeth samples suggests that neither ${ }^{1} \mathrm{H}$ nor ${ }^{13} \mathrm{C} \mathrm{MR}$ signals predict PCR-amplifiable DNA content (D. Mietchen, M. Hofreiter, E.-M. Geigl, unpublished data).

\subsection{Perspectives for fossil MRI}

Perhaps the most obvious limitation for ${ }^{1} \mathrm{H}$ MRI of fossils is their typically low contents of soft-bound ${ }^{1} \mathrm{H}$. A possible strategy to deal with low intrinsic signal intensities is to fill cavities in the specimen of interest with solutions containing sufficient amounts of MR-visible ${ }^{1} \mathrm{H}$ (Sebes et al., 1991; Doughty and Tomutsa, 1996; Steiger et al., 1997; de Swiet et al., 1998; Steiger, 2001; Clark et al., 2004) but, at least in not entirely mouldic fossils, such treatment might impede future chemical analyses, especially of biological macromolecules (Pruvost et al., 2007). In this respect, it would be interesting to find out whether samples that experienced such liquid treatment show any peculiarities in their state of preservation if compared to non-treated samples from the same specimen, though the replacement of the liquids by inert gases (cf. Seeley et al., 2004) could eventually alleviate these concerns.

Besides ${ }^{1} \mathrm{H}$, both MR spectroscopy and MR imaging are in principle possible with all isotopes that possess a net nuclear magnetic moment, i.e. those exhibiting odd numbers of protons or neutrons (e.g. ${ }^{2} \mathrm{H},{ }^{11} \mathrm{~B},{ }^{13} \mathrm{C},{ }^{14} \mathrm{~N},{ }^{15} \mathrm{~N},{ }^{17} \mathrm{O},{ }^{19} \mathrm{~F}$, ${ }^{23} \mathrm{Na},{ }^{25} \mathrm{Mg},{ }^{29} \mathrm{Si},{ }^{31} \mathrm{P}$ and $\left.{ }^{39} \mathrm{~K}\right)$. Since many of these elements play important roles during diagenesis (cf. introduction), such non- ${ }^{1} \mathrm{H}$ constituents might be of special interest for a variety of palaeontological and related studies. The major limiting factor here is sensitivity, whose upper limit in a given static magnetic field depends on the gyromagnetic ratio of the target isotope and on its abundance within the sample, while the practically achievable value is further dependent upon acquisition parameters (for details, see Abragam, 1961; Callaghan, 1991). ${ }^{13} \mathrm{C}$ MR spectroscopy (as in Fig. 6) has already found multiple applications in archaeological research (Lambert et al., 2000), and ${ }^{31} \mathrm{P}$ MRI has been applied to fresh bone and teeth (Li, 1991; Wu et al., 1999).

Furthermore, all states of matter can in principle be investigated but since the MR signal correlates with spin (and thus mass) density, the MR signal obtainable from solid samples (like most fossils) will normally be above that from gaseous and - due to chemical binding strength - below that from liquid samples of similar chemical composition. From this perspective and with our fossil experiments in mind, it is perhaps surprising that, after early MRI studies on mummies had resorted to rehydration (Piepenbrink, 1986) or abandoned imaging alltogether after examining the induction decay signal (Notman et al., 1986), reports of successful MR imaging of non-rehydrated mummies appeared only a few months ago (Karlik et al., 2007; Münnemann et al., 2007). These new findings suggest a reconsideration of MRI for the study of mummified or otherwise preserved ancient tissue samples, e.g. soft tissue recovered from within dinosaur bones (cf. Schweitzer et al., 2005, 2007; Asara et al., 2007), which we expect to yield a stronger MR signal per voxel than the completely mineralised samples shown here.

Mildly frozen specimens like mammoths uncovered from permafrost soil often show remarkable states of soft tissue preservation (Ezra and Cook, 1959; Zimmerman and Tedford, 1976; Cooper, 2006), which sometimes even allows for genome-level genetic analyses (Poinar et al., 2006). Such samples, despite being frozen, still contain considerable amounts of unfrozen water (Koop, 2004) and thus represent another window of opportunity for MR techniques, as demonstrated in sea ice (Eicken et al., 2000) or permafrost samples (Kleinberg and Griffin, 2005).

Another important aspect to be considered is sample size. Firstly, at a given resolution, imaging a larger sample means acquiring more data points and thus longer scanning. Secondly, larger samples generally require larger coils (which will reduce the achievable resolution under otherwise identical conditions), and the ultimate coil size within a given 
imaging setup is limited by the inner diameter of the gradient coils (in our case $38 \mathrm{~mm}$, in human MRI scanners typically around $80 \mathrm{~cm}$ ). Third, although an increase in field strength generally provides for an increase in signal, noise and signalto-noise ratio, a number of artifacts also get more pronounced then (e.g. susceptibility distortions near interfaces with different magnetic susceptibilities). Fourth, there are a number of further parameters relevant to MR measurements (e.g. field homogeneity, sample and coil temperature, gradient strength, filling factor, pulse sequence), and so the choice of the experimental conditions is vital (for details, see Abragam, 1961; Callaghan, 1991; Ernst et al., 1997).

In terms of materials, the only major restriction is that specimens should not exhibit a permanent magnetisation (due to ferro- or paramagnetic constituents) beyond about $10^{-7}$ (i.e. $0.1 \mathrm{ppm}$ ) of the static magnetic field, as this would distort the latter and thus interfere with the way spatial or spectral information are encoded. Fulfilment of this criterion will probably show (like the apical lines in Fig. 2c, d) some taxonomically relevant bias due to biomineralisation or diagenetic environment but this bias is unlikely to extend to higher taxonomic units, and so we suggest that the fossil invertebrate, vertebrate and plant taxa described here should not be seen as a limit but rather taken as starting points for a more detailed screening of fossil lineages by MR techniques.

Comparative evolutionary studies - especially between closely related species, of which only one exhibits a particular trait of interest, while the other does not - have proven useful in and now form the core of most if not all biological disciplines. Palaeontological investigations, specifically, could profit from comparative studies including extant species, thereby complementing the existing knowledge with anatomical and dynamic details concerning processes like post mortem tissue decay (Weigelt, 1927) and in vivo cellular metabolic activities like biomineralisation (e.g. Freytet et al., 1996; Levi et al., 1998; Kolo and Claeys, 2005) as well as embryological development (Xiao, 2002), amber formation (Schmidt and Dilcher, 2007) or locomotion (Gatesy et al., 1999). For all these applications, suitable MR techniques are now in place (e.g. Ciobanu et al., 2003; Manz et al., 2003; Müller et al., 2006; Lee et al., 2006, 2007; Honda and Hata, 2007). This versatility of MR techniques, along with their non-invasiveness, renders them a very promising tool for such comparative investigations (e.g. Hopkins and Rilling, 2000; Spoor et al., 2000; Glidewell et al., 2002).

Ongoing developments in MR technology (Glover and Mansfield, 2002) and the ever wider availability of high-field imaging facilities suggest that MRI will continue to help bypass and circumvent current methodological limitations and to generate more applications in the geosciences (Carlson, 2006) and neighbouring fields. As an example, consider portable NMR devices (Eidmann et al., 1996; Prado, 2003; Blümich et al., 2002; Manz et al., 2006; Marble et al., 2006; Marko et al., 2007; McDonald et al., 2007) which opened up the possibility to examine samples on the spot, be it in the field or in archives. While these devices are currently far from capable of producing images comparable to those presented here, the characteristic relaxation parameters or spectral fingerprints they already can measure could become a valuable non-invasive categorisation tool when screening rock samples for embedded fossils.

\section{Conclusions}

The data presented here demonstrate that MR imaging allows micromorphological details within intact fossils to be studied non-invasively at resolutions down to $50 \mu \mathrm{m}$, i.e. comparable to those of CT images and well below the $100 \mu \mathrm{m}$ that "would be satisfactory [...] for a majority of researchers and for most applications" (Lyons et al., 2000), at least after the Cambrian explosion. The intrinsic MR signal used to acquire the images appears to originate from mobile yet not diffusible water molecules, while the range of specimens suitable for MRI has been extended beyond liquid-filled mouldic or cavernous fossils (Sebes et al., 1991; Steiger, 2001; Clark et al., 2004) and pathological belemnites (Mietchen et al., 2005), so that it now comprises invertebrate, vertebrate and plant specimens obtained from a variety of sites. Moreover, after MRI scanning, all other palaeontological investigations still remain possible - which is not necessarily true in the opposite case. It should be noted that the digital availability of MRI data (as with CT and other modalities; cf. Zollikofer and Ponce de Léon, 2005) renders them ideal for applications like computational morphology (Bookstein, 1996) or rapid prototyping (Zollikofer and Ponce de Léon, 1995) which have a high potential not only in research but also in science education at school or in museums. Taken together, the microscopic resolution currently achieved with MR techniques, their non-invasiveness, the possibility to obtain taxonomically relevant 3-D spatial as well as chemical information, their potentially broad applicability and the multitude of ongoing efforts to further improve them all suggest they could open up complementary avenues for non-invasive approaches to a wide range of palaeobiological issues.

Acknowledgements. We wish to thank W. Eckloff and S. Füting (Lübeck) for providing the kentrodontid periotics, H. Keupp (Berlin) for helpful discussions and E.-M. Geigl (Paris) as well as Y. Fernández-Jalvo (Madrid) and K. Kupczik (Leipzig) for commenting on earlier drafts of the manuscript.

Edited by: T. W. Lyons 


\section{References}

Abelson, P. H.: Organic constituents of fossils, Carnegie Inst. Wash. Year Book, 53, 97-101, 1954.

Aberhan, M., Bussert, R., Heinrich, W.-D., Schrank, E., Schultka, S., Sames, B., Kriwet, J., and Kapilima, S.: Palaeoecology and depositional environments of the Tendaguru Beds (Late Jurassic to Early Cretaceous, Tanzania), Mitt. Mus. f. Naturkunde Berl. Geowiss. Reihe, 5, 19-44, 2002.

Abragam, A.: The Principles of Nuclear Magnetism, Clarendon, Oxford, 1961.

Aines, R. D. and Rossman, G. R.: Water in minerals? A peak in the infrared, J. Geophys. Res., 89B, 4059-4071, 1984.

Albrecht, P. and Ourisson, G.: Biogenic substances in sediments and fossils, Angew. Chem. Int. Ed. Engl., 10, 209-225, 1971.

Andrew, E. R.: Magic Angle Spinning in Solid State n. m. r. Spectroscopy, Phil. Trans. R. Soc. Lond. A, 299, 505-520, 1981.

Asara, J. M., Schweitzer, M. H., Freimark, L. M., Phillips, M., and Cantley, L. C.: Protein Sequences from Mastodon and Tyrannosaurus rex Revealed by Mass Spectrometry, Science, 316, 280-285, doi:10.1126/science.1137614, 2007.

Ausich, W. I., Brett, C. E., Hess, H., and Simms, M. J.: Crinoid form and function, in: Fossil Crinoids, edited by: Hess, H., Ausich, W. I., Brett, C. E., and Simms, M. J., Cambridge University Press, Cambridge, 3-30, 1999.

Bandel, K. and Spaeth, C.: Structural differences in the ontogeny of some belemnite rostra, in: Cephalopods present and past, edited by: Wiedmann, J. and Kullmann, J., Schweizerbart, Stuttgart, 247-271, 1988.

Barnes, L. G.: The late Miocene dolphin Pithanodelphis Abel, 1905 (Cetacea: Kentriodontidae) from California, Contr. Sci. Nat. Hist. Mus. Los Angeles Co., 367, 1-27, 1985.

Behrensmeyer, A. K.: Taphonomic and Ecologic Information from Bone Weathering, Paleobiol., 4, 150-162, 1978.

Behrensmeyer, A. K., Kidwell, S. M., and Gastaldo, R. A.: Taphonomy and paleobiology, Paleobiol., 26, 103-147, 2000.

Berta, A. and Sumich, J. L.: Marine mammals: Evolutionary biology, Academic Press, San Diego, 494 pp., 1999.

Blumer, M.: Organic pigments: their long-term fate, Science, 149, 722-726, 1965.

Blümich, B., Anferov, V., Anferova, S., Klein, M., Fechete, R., Adams, M., and Casanova, F.: Simple NMR-mouse with a bar magnet, Conc. Magn. Reson. B (Magn. Reson. Eng.), 15, 255261, 2002.

Bocherens, H., Tresset, A., Wiedemann, F., Giligny, F., Lafage, F., Lanchon, Y., and Mariotti, A.: Diagenetic evolution of mammal bones in two French Neolithic sites, Bull. Soc. Géol. France, 168, 555-564, 1997.

Bookstein, F.: Biometrics, biomathematics and the morphometric synthesis, Bull. Math. Biol., 58, 313-365, 1996.

Borah, B., Gross, G. J., Dufresne, T. E., Smith, T. S., Cockman, M. D., Chmielewski, P. A., Lundy, M. W., Hartke, J. R., and Sod, E. W.: Three-dimensional microimaging (MRmicroI and microCT), finite element modeling, and rapid prototyping provide unique insights into bone architecture in osteoporosis, Anat. Rec., 265, 101-110, doi:10.1002/ar.1060, 2001.

Boyce, C. K., Hazen, R. M., and Knoll, A. H.: Nondestructive, in situ, cellular-scale mapping of elemental abundances including organic carbon in permineralized fossils, Proc. Natl. Acad. Sci. USA, 98, 5970-5974, doi:10.1073/pnas.101130598, 2001.
Boyce, C. K., Cody, G. D., Feser, M., Jacobsen, C., Knoll, A. H., and Wirick, S.: Organic chemical differentiation within fossil plant cell walls detected with X-ray spectromicroscopy, Geology, 30, 1039-1042, 2002.

Briggs, D. E. G.: The role of decay and mineralization in the preservation of soft-bodied fossils, Annu. Rev. Earth Planet. Sci., 31, 275-301, doi:10.1146/annurev.earth.31.100901.144746, 2003.

Brocks, J. J., Logan, G. A., Buick, R., and Summons, R. E.: Archean Molecular Fossils and the Early Rise of Eukaryotes, Science, 285, 1033-1036, 1999.

Calder, M. G.: A coniferous petrified forest in Patagonia, Bull. Brit. Mus. (Nat. Hist.) Geology, 2, 99-138, 1953.

Callaghan, P. T.: Principles of Nuclear Magnetic Resonance Microscopy, Oxford University Press, Clarendon, 1991.

Carlson, W. D.: Three-dimensional imaging of earth and planetary materials, Earth Planet. Sci. Lett., 249, 133-147, 2006.

Chudek, J. A. and Hunter, G.: Magnetic resonance imaging of plants, Progr. Nucl. Magn. Reson. Spectr., 31, 43-62, 1997.

Ciobanu, L., Webb, A., and Pennington, C.: Magnetic resonance imaging of biological cells, Prog. Nucl. Magn. Reson. Spectrosc., 42, 69-93, 2003.

Clark, N. D. L., Adams, C., Lawton, T., Cruickshank, A. R., and Woods, K.: The Elgin marvel: using magnetic resonance imaging to look at a mouldic fossil from the Permian of Elgin, Scotland, UK, Magn. Reson. Imaging, 22, 269-273, doi: 10.1016/j.mri.2003.09.006, 2004.

Collins, M. J. and Gernaey-Child, A. M.: Fossilized Materials: Proteins, in: Palaeobiology II, edited by Briggs, D. E. G. and Crowther, P. R., Blackwell Science Inc., Cambridge, Massachussetts, 247-271, 2001.

Collins, M. J., Riley, M. S., Child, A. M., and Turner-Walker, G.: A basic mathematical simulation of the chemical degradation of ancient collagen, J. Archaeol. Sci., 22, 175-183, 1995.

Collins, M. J., Nielsen-Marsh, C. M., Hiller, J., Smith, C. I., Roberts, J. P., Prigodich, R. V., Wess, T. J., Csapò, J., Millard, A. R., and Turner-Walker, G.: The Survival of Organic Matter in Bone: A Review, Archaeometry, 44, 383-394, 2002.

Cooper, A.: The Year of the Mammoth, PLoS Biol., 4, e78, 2006.

Crenshaw, M. A.: Biomineralization mechanisms, in: Skeletal Biomineralization: Patterns, Processes and Evolutionary Trends, edited by: Carter, J. G., Van Nostrand Reinhold, New York, 1-9, 1990.

Darrow, B. S.: A fossil araucarian embryo from the Cerro Cuadrado of Patagonia, Bot. Gaz., 98, 328-337, 1936.

Dauphin, Y.: Fossil organic matrices of the Callovian aragonitic ammonites from Lukow (Poland): location and composition, Int J. Earth Sci., 93, 1071-1080, 2002.

de Muizon, C.: Les vertébrés fossiles de la formation Pisco (Perou) III. Troisième partie: Les Odontocètes (Cetacea, Mammalia) du Miocène, Inst. Fr. Étud. And. Mèm., 78, 1-240, 1988.

de Swiet, T. M., Tomaselli, M., Hürlimann, M. D., and Pines, A.: In Situ NMR Analysis of Fluids Contained in Sedimentary Rock, J. Magn. Reson., 133, 385-387, doi:10.1006/jmre.1998.1459, 1998.

Dernbach, U., Jung, W., Selmeier, A., Götz, K., and Fine, H.: Araucaria. The petrified Araucarias from the Cerro Cuadrado, Argentina, D’Oro Verlag, Lorsch, 1992.

DeVore, M. L., Kenrick, P., Pigg, K. B., and Ketcham, R. A.: Utility of high resolution X-ray computed tomography (HRXCT) for 
paleobotanical studies: an example using London Clay fruits and seeds, Am. J. Botany, 93, 1848-1851, 2006.

Dietrich, W.: Zur Stratigraphie und Palaeontologie der Tendaguruschichten, Palaeontographica, II (Suppl. VII, part 2), 1-86, 1933.

Domanus, J. C.: Practical Neutron Radiography, Kluwer, Dordrecht, Netherlands, 1992.

Donoghue, P. C., Bengtson, S., Dong, X. P., Gostling, N. J., Huldtgren, T., Cunningham, J. A., Yin, C., Yue, Z., Peng, F., and Stampanoni, M.: Synchrotron X-ray tomographic microscopy of fossil embryos., Nature, 442, 680-3, 2006.

Doughty, D. A. and Tomutsa, L.: Multinuclear NMR microscopy of two-phase fluid systems in porous rock., Magn. Reson. Imaging, 14, 869-73, 1996.

Drum, R. W.: Silification of Betula woody tissue in vitro, Science, 161, 175-176, 1968.

Dunca, E., Doguzhaeva, L., Schöne, B. R., and Van de Schootbrugge, B.: Growth patterns in rostra of the middle jurassic belemnite Megateuthis giganteus: controlled by the moon?, Geolines, in press, 2008.

Durand, B.: A History of Organic Geochemistry, Oil Gas Sci. Technol. Rev. IFP, 58, 203-231, 2003.

Eglinton, G. and Logan, G. A.: Molecular preservation, Philos. Trans. R. Soc. Lond. B Biol. Sci., 333, 315-327, 1991.

Eicken, H., Bock, C., Wittig, R., Miller, H., and Poertner, H.O.: Magnetic resonance imaging of sea-ice pore fluids: methods and thermal evolution of pore microstructure, Cold Regions Sci. Technol., 31, 207-225, 2000.

Eidmann, G., Savelsberg, R., Blümler, P., and Blümich, B.: The NMR MOUSE, a Mobile Universal Surface Explorer, J. Magn. Reson. A, 122, 104-109, 1996.

Engel, M. H., Goodfriend, G. A., Qian, Y., and Macko, S. A.: Indigeneity of organic matter in fossils: a test using stable isotope analysis of amino acid enantiomers in Quaternary mollusk shells, Proc. Natl. Acad. Sci. U S A, 91, 10 475-10 478, 1994.

Ernst, G.: Stratigraphische und gesteinschemische Untersuchungen im Santon und Campan von Lägerdorf (SW-Hostein), Mitt. Geol. Staatsinst. Hamburg, 32, 71-127, 1963.

Ernst, R. R., Bodenhausen, G., and Wokaun, A.: Principles of Nuclear Magnetic Resonance in One and Two Dimensions, Oxford University Press, Clarendon, 1997.

Ezra, H. C. and Cook, S. F.: Histology of Mammoth Bone, Science, 129, 465-466, 1959.

Feng, Q. L., Li, H. B., Cui, F. Z., Li, H. D., and Kim, T. N.: Crystal orientation domains found in the single lamina in nacre of the Mytilus edulis shell, J. Mat. Sci. Lett., 18, 1547-1549, 1999.

Feng, Q. L., Li, H. B., Pu, G., Zhang, D. M., Cui, F. Z., Li, H. D., and Kim, T. N.: Crystallographic alignment of calcite prisms in the oblique prismatic layer of Mytilus edulis shell, J. Mat. Sci., 35, 3337-3340, 2000.

Ferguson, D. K.: The origin of leaf-assemblages - New light on an old problem, Rev. Palaeobot. Palynol., 46, 117-188, 1985.

Fleischer, G.: Evolutionary principles of the mammalian middle ear, Adv. Anat. Embryol. Cell Biol., 55, 1-70, 1978.

Florek, M., Youn, H. S., Ro, C.-U., Wierzbowski, H., Osán, J., Kazimierczak, W., and Kuczumow, A.: Investigation of chemical composition of belemnite rostra by synchrotron-based X-ray microfluorescence and diffraction and electron microprobe, J. Alloys Comp., 362, 99-106, doi:10.1016/S0925-8388(03)00569-3,
2004.

Florkin, M.: Paléoproteines, Bull. Acad. Roy. Belg. Cl. Sci. (Sér. 5), 51, 156-169, 1965.

Freytet, P., Kerp, H., and Broutin, J.: Permian freshwater stromatolites associated with the conifer shoots Cassinisia orobica Kerp et al. - a very peculiar type of fossilization, Rev. Palaeobot. Palynol., 91, 85-105, 1996.

Friis, E. M., Bengtson, S., Donoghue, P. C. J., and Stampanoni, M.: Secrets of Cretaceous flowers unravelled by X-ray tomography, in: Proceedings of the Second International Palaeontological Congress, 17-21 June 2006, Beijing, China, 3-4, 2006.

Fujiwara, S.-I., Oji, T., Tanaka, Y., and Kondo, Y.: Relay strategy and adaptation to a muddy environment in Isselicrinus (Isselicrinidae: Crinoidea), Palaios, 20, 241-248, 2004.

Gabel, F., Bicout, D., Lehnert, U., Tehei, M., Weik, M., and Zaccai, G.: Protein dynamics studied by neutron scattering, Quart. Rev. Biophys., 35, 327-367, 2002.

Gaffey, S.: Water in skeletal carbonates, J. Sedim. Petrol., 68, 397414, 1988.

Gaffey, S. J.: $\mathrm{H} 2 \mathrm{O}$ and $\mathrm{OH}$ in echinoid calcite: A spectroscopic study, Am. Mineralogist, 80, 947-959, 1995.

Garroway, A. N., Vander Hart, D. L., and Earl, W. L.: ${ }^{13}$ C n. m. r. in organic solids: limits to spectral resolution and to determination of molecular motion, Phil. Trans. R. Soc. Lond. A, 299, 609-628, 1981.

Gastaldo, R.: Plant taphonomic character of Late Carboniferous Hamilton Quarry, Kansas, USA: preservational modes of Walchian conifers and implied relationships for residency time in aquatic environments, in: Palaeovegetational development in Europe and regions relevant to its palaeofloristic evolution, edited by: Kovar-Eder, J., Proc. Pan-European Palaeobot. Conf. Mus. Nat. Hist. Vienna, Vienna, 393-399, 1991.

Gatesy, S. M., Middleton, K. M., Jenkins Jr., F. A., and Shubin, N. H.: Three-dimensional preservation of foot movements in Triassic theropod dinosaurs, Nature, 399, 141-144, 1999.

Glidewell, S. M., Möller, M., Duncan, G., Mill, R. R., Masson, D., and Williamson, B.: NMR imaging as a tool for noninvasive taxonomy: comparison of female cones of two Podocarpaceae, New Phytol., 154, 197-207, 2002.

Glover, P. and Mansfield, P.: Limits to magnetic resonance microscopy, Rep. Prog. Phys., 65, 1489-1511, doi:10.1088/00344885/65/10/203, 2002.

Gothan, W.: Über die merkwürdigen feigenartigen Kieselknöllchen aus dem versteinerten Wald des Cerro Cuadrado in Patagonien, Miscellania Academica Berolinensia, Gesammelte Abhandlungen zur Feier des 250-jährigen Bestehens der Deutschen Akademie der Wissenschaften zu Berlin, I, 149-154, 1950.

Gripp, K.: Erdgeschichte von Schleswig-Holstein, Wachholtz, Neumünster, 1964.

Hampe, O.: Bestandsaufnahme der Walfauna (Mammalia: Cetacea) aus dem untersten Obermiozän (oberes Langenfeldium) von Groß Pampau (Schleswig-Holstein), Ber. Ver. "Nat. Heimat" Naturhist. Mus. Lübeck, 25/26, 87-107, 1999.

Hedges, R. E. M. and Millard, A. R.: Bones and groundwater: towards the modelling of diagenetic processes, J. Archaeol. Sci., 22, 155-164, 1995.

Hedges, R. E. M., Millard, A. R., and Pike, A. W. G.: Measurements and relationships of diagenetic alteration of bone from three archaeological sites, J. Archaeol. Sci., 22, 201-209, 1995. 
Heinzeller, T. and Welsch, U.: Crinoidea, in: Fossil Crinoids, Vol. 14, Echinodermata, edited by: Harrison, F. W. and Chia, F.-S., Wiley, New York, 9-148, 1994.

Hemsley, A. R., Barrie, P. J., and Scott, A. C.: 13C solid-state nmr spectroscopy of fossil sporopollenins, Fuel, 74, 1009-1012, 1995.

Hinsch, W.: Biostratigraphy of Reinbekian/ Levensauian/ Lüneburgian/ Langenfeldian boundary stratotypes in Pampau area (SE-Holstein), Veröff. Übersee-Mus. Bremen R. A, 10, 5579, 1990.

Honda, Y. and Hata, N.: Dynamic imaging of swallowing in a seated position using open-configuration MRI, J. Magn. Reson. Imaging, 26, 172-176, 2007.

Höpfner, G.: Wale und Haie - aus der Urzeit aufgetaucht, Z. Nat. Landeskd. S-H u.Hambg., 98, 245-253, 1991.

Hopkins, W. D. and Rilling, J. K.: A Comparative MRI Study of the Relationship Between Neuroanatomical Asymmetry and Interhemispheric Connectivity in Primates: Implication for the Evolution of Functional Asymmetries, Behavior. Neurosci., 114, 739-748, doi:10.1037/0735-7044.114.4.739, 2000.

Hudson, J. D.: The elemental composition of the organic fraction, and the water content, of some recent and fossil mollusc shells, Geochim. Cosmochim. Acta, 31, 2361-2378, 1967.

Jackson, A. P., Vincent, J. F. V., and Turner, R. M.: The Mechanical Design of Nacre, Phil. Trans. R. Soc. Lond. B, 234, 415-440, 1988.

Janensch, W.: Die Gliederung der Tendaguru-Schichten im Tendaguru-Gebiet und die Entstehung der Saurier-Lagerstätten, Archiv Biontol., 3, 227-261, 1914.

Kalinowski, H.-O., Berger, S., and Braun, S.: ${ }^{13}$ C NMRSpektroskopie, Georg Thieme Verlag, Stuttgart, 1984.

Karlik, S. J., Bartha, R., Kennedy, K., and Chhem, R.: MRI and Multinuclear MR Spectroscopy of 3,200-Year-Old Egyptian Mummy Brain, Am. J. Roentgenol. 189:105-110, 2007.

Ketten, D. R. and Wartzok, D.: Three-dimensional reconstructions of the dolphin ear, in: Sensory abilities of cetaceans, edited by: Thomas, J. and Kastelein, R., Plenum Press, New York, 81-105, 1990.

Kidwell, S. M. and Holland, S. M.: The quality of the fossil record: Implications for evolutionary analyses, Annu. Rev. Ecol. Syst., 33, 561-588, doi:10.1146/annurev.ecolsys.33.030602.152151, 2002.

Kleinberg, R. and Griffin, D.: NMR measurements of permafrost: unfrozen water assay, pore-scale distribution of ice, and hydraulic permeability of sediments, Cold Regions Science and Technology, 42, 63-77, 2005.

Kolo, K. and Claeys, P.: In vitro formation of Ca-oxalates and the mineral glushinskite by fungal interaction with carbonate substrates and seawater, Biogeosciences, 2, 277-293, 2005, http://www.biogeosciences.net/2/277/2005/.

Koop, T.: Homogeneous Ice Nucleation in Water and Aqueous Solutions, Z. Phys. Chem., 218, 1231-1258, 2004.

Lambert, J. B., Shawl, C. E., and Stearns, J. A.: Nuclear magnetic resonance in archaeology, Chem. Soc. Rev., 29, 175-182, doi:10.1039/a908378b, 2000

Lee, S., Cho, J., Mietchen, D., Kim, Y., Hong, K., Lee, C., Kang, D., Park, K., Choi, B., and Cheong, C.: Subcellular In Vivo ${ }^{1} \mathrm{H}$ MR Spectroscopy of Xenopus laevis Oocytes, Biophys. J., 90, 1797-1803, 2006.
Lee, S., Mietchen, D., Cho, J., Kim, Y., Kim, C., Hong, K., Lee, C., Kang, D., Lee, W., and Cheong, C.: In vivo magnetic resonance microscopy of differentiation in Xenopus laevis embryos from the first cleavage onwards, Differentiation, 75, 84-92, 2007.

Levi, Y., Albeck, S., Brack, A., Weiner, S., and Addadi, L.: Control Over Aragonite Crystal Nucleation and Growth: An In Vitro Study of Biomineralization, Chem. - Eur. J., 4, 389-396, 1998.

Li, L.: A new technique for solid NMR imaging and application to phosphorus imaging in solid bone, Phys. Med, 36, 199-206, 1991.

Liem, K. F., Bemis Jr., W. E., Walker, F. W., and Grande, L.: Functional anatomy of the vertebrates. An evolutionary perspective, Harcourt, Fort Worth, 2001.

Lowenstam, H. A. and Weiner, S.: On Biomineralization, Oxford University Press, New York, 1989.

Lowenstein, J.: Immunological Reactions from Fossil Material, Philos. Trans. R. Soc. Lond. B: Biol. Sci., 292, 143-149, 1981.

Luo, Z. and Eastman, E. R.: Petrosal and inner ear of a squalodontid whale: implications for evolution of hearing in odontocetes, J. Vert. Paleont., 15, 431-442, 1995.

Luo, Z. and Marsh, K.: Petrosal (periotic) and inner ear of a Pliocene kogiine whale (Kogiinae, Odontoceti): implications on relationships and hearing evolution of toothed whales, J. Vert. Paleont., 16, 328-348, 1996.

Luo, Z., Chen, P., Li, G., and Chen, M.: A new eutriconodont mammal and evolutionary development in early mammals, Nature, 446, 288-293, 2007.

Lyons, P. D., Rioux, M., and Patterson, R. T.: Application of a Three-Dimensional Color Laser Scanner to $\mathrm{Pa}$ leontology: an Interactive Model of a Juvenile Tylosaurus sp. Basisphenoid-Basioccipital, Palaeontol. Electron., 3, 16 pp., http://palaeo-electronica.org/2000_2/neural/issue2_00.htm, 2000.

Majumdar, S., Kothari, M., Augat, P., Newitt, D., Link, T., Lin, J., Lang, T., Lu, Y., and Genant, H.: High-resolution magnetic resonance imaging: three-dimensional trabecular bone architecture and biomechanical properties, Bone, 22, 445-454, 1998.

Mansfield, P.: Multiple-Pulse Nuclear Magnetic Resonance Transients in Solids, Phys. Rev., 137, 961-974, 1965.

Manz, B., Volke, F., Goll, D., and Horn, H.: Measuring local flow velocities and biofilm structure in biofilm systems with Magnetic Resonance Imaging (MRI), Biotechnol. Bioengin., 84, 424-432, 2003.

Manz, B., Coy, A., Dykstra, R., Eccles, C., Hunter, M., Parkinson, B., and Callaghan, P.: A mobile one-sided NMR sensor with a homogeneous magnetic field: The NMR-MOLE, J. Magn. Reson., 183, 25-31, 2006.

Marble, A. E., Mastikhin, I. V., Colpitts, B. G., and Balcom, B. J.: A constant gradient unilateral magnet for near-surface MRI profiling, J. Magn. Reson., 183, 228-234, 2006.

Marino, L., Uhen, M. D., Pyenson, N. D., and Frohlich, B.: Reconstructing cetacean brain evolution using computed tomography, Anat. Record, 272, 107-117, 2003.

Marko, A., Wolter, B., and Arnold, W.: Application of a portable nuclear magnetic resonance surface probe to porous media, J. Magn. Reson., 185, 19-27, doi:10.1016/j.jmr.2006.10.009, 2007.

Martill, D. M.: Bones as stones: the contribution of vertebrate remains to the lithologic record, in: The processes of fossilization, 
edited by: Donovan, S. K., Belhaven, London, 270-292, 1991.

Martin, R. F. and Donnay, G.: Hydroxyl in the mantle, Am. Mineral., 57, 554-570, 1972.

Mazurier, A., Volpato, V., and Macchiarelli, R.: Improved noninvasive microstructural analysis of fossil tissues by means of SRmicrotomography, Appl. Phys. A, 83, 229-233, 2006.

McDonald, P. J., Aptaker, P. S., Mitchell, J., and Mulheron, M.: A unilateral NMR magnet for sub-structure analysis in the built environment: The Surface GARField., J. Magn. Reson., 185, 111, doi:10.1016/j.jmr.2006.11.001, 2007.

Menéndez, C. A.: Cono masculine de una conífera fósil del Bosque Petrificado de Santa Cruz, Ameghiniana, 2, 11-17, 1960.

Middelburg, J. J. and Meysman, F. J. R.: Burial at Sea, Science, 316, 1294-1295, 2007.

Mietchen, D., Keupp, H., Manz, B., and Volke, F.: Non-invasive diagnostics in fossils - Magnetic Resonance Imaging of pathological belemnites, Biogeosciences, 2, 133-140, 2005, http://www.biogeosciences.net/2/133/2005/.

Mill, R. R., Möller, M., Christie, F., Glidewell, S. M., Masson, D., and Williamson, B.: Morphology, Anatomy and Ontogeny of Female Cones in Acmopyle pancheri (Brongn. \& Gris) Pilg. (Podocarpaceae), Ann. Bot.-London, 88, 55-67, 2001.

Millard, A. R. and Hedges, R. E. M.: The role of the environment in uranium uptake by buried bone, J. Archaeol. Sci., 22, 239-250, 1995.

Miller, G. S.: The telescoping of the Cetacean skull, Smithson. Misc. Coll., 76, 1-71, 1923.

Mills, R.: Self-diffusion in normal and heavy water in the range $1-45^{\circ} \mathrm{C}$, J. Phys. Chem., 77, 685-688, 1973.

Müller, W. E. G., Kaluzhnaya, O. V., Belikov, S. I., Rothenberger, M., Schröder, H. C., Reiber, A., Kaandorp, J. A., Manz, B., Mietchen, D., and Volke, F.: Magnetic Resonance Imaging of the siliceous skeleton of the demosponge Lubomirskia baicalensis, J. Struct. Biol., 153, 31-41, doi:10.1016/j.jsb.2005.09.008, 2006.

Münnemann, K., Böni, T., Colacicco, G., Blümich, B., and Rühli, F.: Noninvasive ${ }^{1} \mathrm{H}$ and ${ }^{23} \mathrm{Na}$ nuclear magnetic resonance imaging of ancient Egyptian human mummified tissue. Magn. Reson. Imaging 25:1341-1345, 2007.

Myers, H. M.: Trapped water in dental enamel, Nature, 206, 713$714,1965$.

Naef, A.: Die fossilen Tintenfische, Gustav Fischer Verlag, Jena, 1922.

Neugebauer, J.: Micritization of crinoids by diagenetic dissolution, Sedimentology, 25, 267-283, 1978.

Newesely, H.: Fossil bone apatite, Appl. Geochem., 4, 233-245, 1989.

Nielsen-Marsh, C. M. and Hedges, R. E. M.: Patterns of diagenesis in bone I: the effects of site environments, J. Archaeol. Sci., 27, 1139-1150, 2000.

Nielsen-Marsh, C. M., Hedges, R. E. M., Mann, T., and Collins, M. J.: A preliminary investigation of the application of differential scanning calorimetry to the study of collagen degradation in archaeological bone, Thermochim. Act., 365, 129-139, 2000.

Niklas, K. J. and Gensel, P. G.: Chemotaxonomy of some Paleozoic vascular plants. Part I: chemical compositions and preliminary cluster analyses, Brittonia, 28, 353-378, 1976.

Notman, D. N. H., Tashjian, J., Aufderheide, A. C., Cass, O. W., Shane III, O. C., Berquist, T. H., Gray, J. E., and Gedgaudas, E.: Modern Imaging and Endoscopic Biopsy Techniques in Egyptian
Mummies, Am. J. Radiol., 146, 93-96, 1986.

Nummela, S., Reuter, T., Hemilä, S., Holmberg, P., and Paukku, P.: The anatomy of the killer whale middle ear (Orcinus orca), Hearing Res., 133, 61-70, 1999.

Oji, T.: Early Cretaceous Isocrinus from Northeast Japan, Palaeontology, 28, 661-674, 1985.

Oji, T.: Miocene Isocrinidae (stalked crinoids) from Japan and their biogeographic implication, Trans. Proc. Paleontol. Soc. Jpn. N. S., 157, 412-429, 1990.

Ourisson, G. and Nakatani, Y.: The terpenoid theory of the origin of cellular life: the evolution of terpenoids to cholesterol, Chem. Biol., 1, 11-23, 1994.

Pääbo, S., Poinar, H., Serre, D., Jaenicke-Després, V., Hebler, J., Rohland, N., Kuch, M., Krause, J., Vigilant, L., and Hofreiter, M.: Genetic analyses from ancient DNA, Annu. Rev. Gen., 38, 645-679, doi:10.1146/annurev.genet.37.110801.143214, 2004.

Pfretzschner, H.-U.: Zerstörungsfreie Alters-Abschätzung fossiler Knochen mit Hilfe von Radioisotopen, N. Jb. Geol. Paläont. Abh., 206, 181-196, 1997.

Pfretzschner, H.-U.: Frühdiagenetische Prozesse bei der Fossilisation von Knochen, N. Jb. Geol. Paläont. Abh., 210, 369-397, 1998.

Pfretzschner, H.-U.: Pyrite formation in Pleistocene bones - a case of very early mineral formation during diagenesis, N. Jb. Geol. Paläont. Abh., 217, 143-160, 2000.

Piepenbrink, H., Frahm, J., Haase, A., and Matthaei, D.: Nuclear magnetic resonance imaging of mummified corpses, Am. J. Phys. Anthropol., 70, 27-28, 1986.

Piepenbrink, H.: Examples of chemical changes during fossilisation, Appl. Geochem., 4, 273-280, doi:10.1016/08832927(89)90029-2, 1989.

Pilleri, G., Gihr, M., and Kraus, C.: The organ of hearing in Cetaceans. 1. Recent species, Invest. Cetacea, 20, 43-125, 1987.

Poinar, H. N., Schwarz, C., Qi, J., Shapiro, B., Macphee, R. D., Buigues, B., Tikhonov, A., Huson, D., Tomsho, L. P., Auch, A., et al.: Metagenomics to Paleogenomics: Large-Scale Sequencing of Mammoth DNA., Science, 311, 392-394, 2006.

Prado, P. J.: Single sided imaging sensor, Magn. Reson. Imaging, 21, 397-400, 2003.

Pruvost, M., Schwarz, R., Correia, V. B., Champlot, S., Braguier, S., Morel, N., Fernández-Jalvo, Y., Grange, T., and Geigl, E.-M.: Freshly excavated fossil bones are best for amplification of ancient DNA, PNAS, 104, 739-744, doi:10.1073/pnas.0610257104, 2007.

Purves, P. E. and Pilleri, G.: Echolocation in whales and dolphins, Academic Press, London, 1983.

Rossman, G. R.: Analytical Methods for Measuring Water in Nominally Anhydrous Minerals, Rev. Mineral. Geochem., 62, 1-28, 2006.

Rothman, D. H. and Forney, D. C.: Physical Model for the Decay and Preservation of Marine Organic Carbon, Science, 316, 13251328, 2007.

Rothwell, W. and Vinegar, H.: Petrophysical applications of NMR imaging, Appl. Opt., 24, 3969-3972, 1985.

Rottländer, R. C. A.: Knochendiagenese als Datierungshilfe, N. Jb. Geol. Paläont. Abh., 157, 185-187, 1979.

Sælen, G.: Diagenesis and construction of the belemnite rostrum, Palaeontol., 32, 765-798, 1989.

Schmidt, A. R. and Dilcher, D. L.: Aquatic organisms as amber in- 
clusions and examples from a modern swamp forest, Proc. Natl. Acad. Sci. USA, 104, 16581-16 585, 2007.

Schwarz, D., Vontobel, P., Lehmann, E. H., Meyer, C. A., and Bongartz, G.: Neutron Tomography of Internal Structures of Vertebrate Remains: A Comparison with X-ray Computed Tomography, Palaeontol. Electron., 8, 30A, http://palaeo-electronica.org/ paleo/2005_2/icht/issue2_05.htm, 2005.

Schweitzer, M. H.: The Future of Molecular Biology, Palaeontol. Electron., 5, 2, http://palaeo-electronica.org./2002_2/editor/ r_and_p.htm, 2003.

Schweitzer, M. H., Wittmeyer, J. L., Horner, J. R., and Toporski, J. K.: Soft-tissue vessels and cellular preservation in Tyrannosaurus rex, Science, 307, 1952-1955, doi:10.1126/science.1108397, 2005.

Schweitzer, M. H., Suo, Z., Avci, R., Asara, J. M., Allen, M. A., Arce, F. T., and Horner, J. R.: Analyses of Soft Tissue from Tyrannosaurus rex Suggest the Presence of Protein, Science, 316, 277-280, doi:10.1126/science.1138709, 2007.

Scott, A. C. and Collinson, M. E.: Non-destructive multiple approaches to interpret the preservation of plant fossils: implications for calcium-rich permineralizations, J. Geol. Soc. London, $160,857-862,2003$.

Sebes, J. I., Langston, J. W., Gavant, M. L., and Rothschild, B. M.: Magnetic resonance imaging of growth recovery lines in fossil vertebrae, Amer. J. Roentgenol., 157, 415-416, 1991.

Seeley, J., Han, S., and Pines, A.: Remotely detected high-field MRI of porous samples, J. Magn. Reson., 167, 282-290, 2004.

Sigleo, A. C.: Organic geochemistry of silicified wood, Petrified Forest National Park, Arizona, Geochim. Cosmochim. Acta, 42, 1397-1405, 1978.

Siurek, J., Chevallier, P., Ro, C.-U., Chun, H. Y., Youn, H. S., Zięba, E., and a. Kuczumov: Studies on the wood tissue substitution by silica and calcites during the preservation of fossil wood, J. Alloys Compounds, 362, 107-115, 2004.

Siveter, D. J., Sutton, M. D., Briggs, D. E. G., and Siveter, D. J.: A Silurian sea spider, Nature, 431, 978-980, 2004.

Spiegler, D. and Gürs, K.: Der miozäne Glimmerton von Groß Pampau, Schleswig-Holstein (Mollusken, Foraminiferen und Bolboformen), Meyniana, 48, 135-164, 1996.

Spoor, F., Jeffery, N., and Zonneveld, F.: Imaging skeletal growth and evolution, in: Development, Growth and Evolution: Implications for the Study of the Hominid Skeleton, edited by: O'Higgins, P. and Cohn, M., Academic Press, London, 123-161, 2000.

Spoor, F., Bajpai, S., Hussain, S. T., Kumar, K., and Thewissen, J. G. M.: Vestibular evidence for the evolution of aquatic behaviour in early cetaceans, Nature, 417, 163-166, 2002.

Steiger, T.: Nuclear magnetic resonance imaging in paleontology, Comput. Geosci., 27, 493-495, 2001.

Steiger, T., Kirsch, K.-H., Groß, D., and Lehmann, V.: Die Anwendung der Kernspintomographie in der Paläontologie, Geol. B1. NO-Bayern, 47, 339-356, 1997.

Stejskal, E. O. and Tanner, J. E.: Spin Diffusion Measurements: Spin Echoes in the Presence of a Time-Dependent Field Gradient, J. Chem. Phys., 42, 288-292, 1965.

Stockey, R. A.: Seeds and embryos of Araucaria mirabilis, Am. J. Bot., 62, 856-868, 1975.

Stockey, R. A.: Reproductive biology of the Cerro Cuadrado (Jurassic) fossil conifers: Pararaucaria patagonica, Am. J. Bot., 64,
733-744, 1977.

Sutton, M. D., Briggs, D. E. G., Siveter, D. J., and Siveter, D. J.: Methodologies for the Visualization and Reconstruction of Three-dimensional Fossils from the Silurian Herefordshire Lagerstätte, Palaeontol. Electron., 4, 1, http://palaeo-electronica. org/2001_1/s2/issue1_01.htm, 2001.

Sutton, M. D., Briggs, D. E. G., Siveter, D. J., and Siveter, D. J.: Silurian brachiopods with soft-tissue preservation, Nature, 436, 1013-1015, 2005.

Tafforeau, P., Boistel, R., Boller, E., Bravin, A., Brunet, M., Chaimanee, Y., Cloetens, P., Feist, M., Hoszowska, J., Jaeger, J. J., Kay, R., Lazzari, V., Marivaux, L., Nel, A., Nemoz, C., Thibault, X., Vignaud, P., and Zabler, S.: Applications of X-ray synchrotron microtomography for non-destructive 3D studies of paleontological specimens, Appl. Phys. A, 83, 195-202, 2006.

Treibs, A.: Chlorophyll und Häminderivate in bituminösen Gesteinen, Erdölen, Erdwachsen und Asphalten, Ann. Chem., 510, 42-62, 1934.

Trueman, C. N.: Rare earth element geochemistry and taphonomy of terrestrial vertebrate assemblages, Palaios, 14, 555-568, 1999.

Tsai, H. M., Lin, X. Z., Chen, C. Y., Lin, P. W., and Lin, J. C.: MRI of Gallstones with Different Compositions, Am. J. Roentgenol., 182, 1513-1519, 2004.

Vandenbroucke, M.: Kerogen: from Types to Models of Chemical Structure, Oil Gas Sci. Technol. (Rev. IFP), 58, 243-269, 2003.

Veeman, W. S.: Nuclear magnetic resonance, a simple introduction to the principles and applications, Geoderma, 80, 225-242, 1997.

Veizer, J.: Chemical diagenesis of belemnite shells and possible consequences of paleotemperature determinations, N. Jb. Geol. Paläont. Abh., 147, 91-111, 1974.

Volke, F., Eisenblätter, S., Galle, J., and Klose, G.: Dynamic properties of water at phosphatidylcholine lipid-bilayer surfaces as seen by deuterium and pulsed field gradient proton NMR, Chem. Phys. Lipids, 70, 121-131, 1994.

Waggoner, B.: Molecular palaeontology, Encycl. Life Sci., 12, 227 232, 2002.

Weigelt, J.: Rezente Wirbeltierleichen und ihre paläobiologische Bedeutung, Max Weg Verlag, Leipzig, 1927.

Weiner, S.: Aspartic acid-rich proteins: major components of the soluble organic matrix of mollusk shells, Calc. Tissue Intl., 29, 163-167, 1979.

Weiner, S. and Dove, P. M.: An overview of biomineralization processes and the problem of the vital effect, in: Biomineralization, edited by: Dove, P. M., DeYoreo, J. J., and Weiner, S., Min. Soc. Am., Washington, 1-29, 2003.

Weiner, S., Lowenstam, H. A., and Hood, L.: Characterization of 80-million-year-old mollusk shell proteins, Proc. Natl. Acad. Sci. USA, 73, 2541-2545, 1976.

Westbroek, P., van der Meide, P. H., van der Wey-Kloppers, J. S., van der Sluis, R. J., de Leeuw, J. W., and de Jong, E. W.: Fossil macromolecules from cephalopod shells: characterization, immunological response and diagenesis, Paleobiol., 5, 151-167, 1979.

Wider, G.: Technical Aspects of NMR Spectroscopy with Biological Macromolecules and Studies of Hydration in Solution, Prog. Nucl. Mag. Res. Sp., 32, 3, 193-275, 1998.

Wolkenstein, K., Gross, J., Falk, H., and Schöler, F.: Preservation of hypericin and related polycyclic quinone pigments in fossil crinoids, Proc. Biol. Sci., 273, 451-456, 2006. 
Wu, Y., Chesler, D. A., Glimcher, M. J., Garrido, L., Wang, J., Jiang, H. J., and Ackerman, J. L.: Multinuclear solid-state threedimensional MRI of bone and synthetic calcium phosphates, Proc. Natl. Acad. Sci. USA, 96, 1574-1578, 1999.

Xiao, S.: Mitotic topologies and mechanics of Neoproterozoic algae, Paleobiology, 28, 244-250, 2002.

Zimmerman, M. and Tedford, R.: Histologic structures preserved for 21,300 years, Science, 194, 183-184, 1976.
Zollikofer, C. P. E. and Ponce de Léon, M. S.: Tools for rapid prototyping in the biosciences, IEEE Comp. Graph. Appl., 15, 48-55, 1995.

Zollikofer, C. P. E. and Ponce de Léon, M. S.: Virtual Reconstruction: A Primer in Computer-Assisted Paleontology and Biomedicine, Wiley, New York, 2005. 